\title{
Coding For Life - Should Any EnTity Have The Exclusive Right To Use AND SELL ISOLATED DNA?
}

\author{
By Douglas L. Rogers \\ Volume XII - Fall 2011
}

\begin{abstract}
Myriad Genetics, Inc. ("Myriad") obtained patents in the 1990s on two "isolated" human breast and ovarian cancer susceptibility genes ("BRCA"). Myriad did not list all the isolated sequences it claims to have a right to monopolize, but instead claims a patent on the physical phenomena itself -- all DNA segments that code for the BRCA1 polypeptide, even the sequences Myriad has not identified and even those someone else in the future creates or isolates the sequences of through a method or methods not contemplated by Myriad.
\end{abstract}

An impressive array of non-profit medical societies, doctors and patients sued to have the Myriad patents declared invalid. In 2010, the District Court for the Southern District of New York held in Association for Molecular Pathology v. United States Patent and Trademark Office that the claimed product patents for isolated DNA segments constituted unpatentable subject matter under 35 U.S.C. §101. On July 29, 2011, a divided panel of the Federal Circuit reversed the District Court and held that the isolated DNA segments constituted patentable subject matter.

Of the three member panel, Judge Lourie concluded that the isolated DNA was markedly different than the native DNA, so constituted patentable subject matter. Although Judge Moore agreed that certain DNA segments constituted patentable subject matter, she believed that the longer isolated DNA segments probably did not constitute patentable subject matter. However, primarily in light of the fact that the US Patent and Trademark Office has been granting patents for isolated DNA for years, Judge Moore concurred in the judgment of Judge Lourie. Judge Bryson concurred on one of the product claims (for synthetic cDNA) but dissented on claims pertaining to the isolated DNA segments on the grounds that isolated DNA did not differ markedly from the native DNA and that the function of the isolated DNA was identical to the function of the native DNA.

The Supreme Court stated that "Congress may not authorize the issuance of patents whose effects are to remove existent knowledge from the public domain, or to restrict free access to materials already available." This article argues that the Federal Circuit - not Congress - has done just that and has given Myriad a wall to restrict free access to materials that have literally been in humans for centuries. The isolated DNA segments of claim 1 do exactly the same coding as do the native segments--nothing more; nothing less. The segments of claim 1 do not act as primers or probes, so they do not have markedly different characteristics or utility than native DNA, which the Supreme Court has ruled courts must consider. Moreover, the functioning of the sequence of the nucleotide bases is a physical phenomenon that Myriad has not created but has captured in its claim. Judges Lourie and Moore disregarded Supreme Court precedent and the fundamental principle that physical phenomena are not patentable subject matter. 
Coding For Life - Should Any Entity Have The Exclusive Right To Use AND SELL ISOLATED DNA?

\author{
By Douglas L. Rogers \\ Volume XII - Fall 2011
}

$\begin{array}{ll}\text { I. INTRODUCTION } & 2\end{array}$

II. WHAT IS NOT PATENTABLE 10

A. Product of Nature Doctrine in the Nineteenth Century 10

1. Nineteenth century cases 10

2. Summary of nineteenth century cases 15

B. Modification of Nature in the Twentieth Century 16

1. American Fruit Growers, Inc. 16

2. Funk Bros. Seed Co. 17

3. Chakrabarty 20

4. Lower court purification cases 23

5. Summary of twentieth century cases 27

III. ASSOCIATION FOR MOLECULAR PATHOLOGY vs. U.S. PATENT AND TRADEMARK OFFICE AND MYRIAD GENETICS, INC. 29

A. The Representative Patents 29

B. Is the Isolated DNA Markedly Different than the Native DNA? 31

1. Looking solely at chemical composition 31

2. Judge Lourie rejected considering uses/functioning of isolated DNA in determining whether the "invention" is markedly different than native DNA 32

3. Judge Moore did not identify any different use/functioning of isolated segments of claim 1 from native DNA 34

4. Judge Bryson's dissent that isolated DNA segments are not markedly different $\quad 35$

5. Summary 37

C. Judge Moore's Explanations of Her Concurrence with Judge Lourie 43

1. Expansive scope of statutory patentable subject matter vs. Supreme Court limits on that scope 44

2. USPTO 46

3. Other litigation, settled expectations and property rights 49

4. Summary 55

D. In Addition to Stare Decisis, Patent Policies Support Funk and
Chakrabarty

$\begin{array}{ll}\text { IV. CONCLUSION } & 61\end{array}$

APPENDIX: BIOCHEMISTRY AND THE GENETIC CODE 63

PGH. J. TECH. L. \& POL ‘Y, Vol. 12, No. 3, Fall 2011 
"Before I built a wall I'd ask to know

What I was walling in or walling out,

And to whom I was like to give offence.

Something there is that doesn't love a wall ..."1

\section{INTRODUCTION}

Patents, like walls, exclude. A patent holder can sue anyone who uses her patented product without permission and, with appropriate proof, obtain injunctive relief against the defendant's continued use of the product. $^{2}$ Creating walls in the field of health care, Myriad Genetics, Inc. ("Myriad") obtained patents in the 1990s on two "isolated" human breast and ovarian cancer susceptibility genes ("BRCA") and sued two companies providing clinical BRCA testing for patent infringement. ${ }^{3}$ Issues in those cases could have included:

- Can isolated DNA be the subject of patent protection? ${ }^{4}$

- Do patents on isolated DNA segments harmfully wall off such "products of nature" from use by scientists in medical research and treatment of diseases? ${ }^{5}$

- Does patent protection provide an appropriate incentive for scientists and companies to progress further in the field of medical research and treatment? ${ }^{6}$

${ }^{1}$ Robert Frost, Mending Wall, http://www.poetryfoundation.org/poem/173530 (last visited June 30, 2011).

${ }^{2} 35$ U.S.C. $\S \S 271(\mathrm{a}), 281,283,284$ (2006).

${ }^{3}$ Ass' $n$ for Molecular Pathology v. United States Patent and Trademark Office, 653 F.3d 1329, 1334 (Fed. Cir. 2011) ("The challenged composition claims cover two 'isolated' human genes, BRCA1 and BRCA2 (collectively, 'BRCA1/2' or 'BRCA'), and certain alterations, or mutations, in these genes associated with a predisposition to breast and ovarian cancers.") and 5-7 (Fed. Cir. 2011) [hereinafter AMP2] .

${ }^{4}$ See, e.g., Eileen M. Kane, Patent Ineligibility: Maintaining A Scientific Public Domain, 80 St. JoHN's L. Rev. 519 , 524 (2006) [hereinafter Ineligibility] ("Is it proper to regard scientific knowledge or research tools as subjects of intellectual property?").

${ }^{5}$ See case cited infra note 8 where the Plaintiffs in AMP1 claimed, "Such patents ... would cause more harm than good to society and technological development. In the BRCA context, the existence of the challenged patents has resulted in exclusive genetic testing, thereby limiting access to different types of testing methods and alternative laboratories for patients and their physicians, and produced a chilling effect on research." See also Memorandum of Law (1) in Further Support of Plaintiffs' Motion for Summary Judgment Against All Defendants and (2) in Opposition to the Myriad Defendants' Motion for Summary Judgment and (3) in Opposition to Defendant United States Patent and Trademark Office's Motion for Judgment On the Pleadings, 2010 WL 1048410 (S.D.N.Y.), at*5; Bryan Nese, Bilski On Biotech: The Potential For Limiting The Negative Impact Of Gene Patents, 46 Calif. W. L. Rev. 137, 174 (2009) ("[G]ene patents represent a group of patents that generally hinder innovation and therefore act contrary to the Patent Clause").

${ }^{6}$ See case cited infra note 8 for defendant Myriad's claim in AMPI ("The BRCA patents have not stifled research--in fact, Myriad has consistently promoted and subsidized research on the BRCA genes. Over 18,000 scientists (including eight of the plaintiffs or their declarants) have conducted research on the BRCA1 and BRCA2 genes, and 
However, the defendants agreed to stop the challenged activities, and there was not a ruling on the merits. ${ }^{7}$

Subsequently an impressive array of non-profit medical societies, doctors, and patients sued to have the Myriad patents declared invalid. ${ }^{8}$ In 2010, the District Court for the Southern District of New York held in Association for Molecular Pathology v. United States Patent and Trademark Office ("AMP1") that the claimed patents for isolated DNA segments constituted unpatentable subject matter under 35 U.S.C. $§ 101 .{ }^{9}$ Myriad appealed the decision that all the "challenged claims are drawn to unpatentable subject matter," and on July 29, 2011, in a 2-1 decision, the Federal Circuit reversed the District Court and held that the product claims constituted patentable subject matter ("AMP2"). ${ }^{10}$ No prior court had directly ruled that isolated

have published more than 7,000 papers on those genes since Myriad's patents were issued. And these $B R C A$ patents have catalyzed improved patient access to BRCA testing"). See also Myriad Defendants' Memorandum of Law (1) in Support of Their Motion for Summary Judgment and (2) in Opposition to Plaintiffs' Motion for Summary Judgment, 2009 WL 5785008 (S.D.N.Y.) ,at* 1.

${ }^{7}$ AMP2, 653 F.3d at 1340.

${ }^{8}$ Ass' $\mathrm{n}$ for Molecular Pathology v. United States Patent and Trademark Office, 702 F.Supp.2d 181, 184, 186-189 (S.D.N.Y. March 29, 2010, as amended Apr, 5, 2010) [hereinafter AMP1], aff'd in par, rev'd in part, 653 F.3d 1329 (Fed. Cir. 2011). The plaintiffs included the Association for Molecular Pathology, the American College of Medical Genetics, the American Society for Clinical Pathology, the College of American Pathologists and a number of women diagnosed with breast or ovarian cancer. AMPI at 186-189. One patient diagnosed with breast cancer "sought a second opinion of that test result but learned that Myriad is the only laboratory in the country that can provide full BRCA1/2 sequencing." Id. at 189.

${ }^{9}$ The court granted Plaintiffs' motion for summary judgment in part, denied Myriad's motion for summary judgment and granted the motion for judgment on the pleadings filed by the U.S. Patent and Trademark Office (USPTO). $A M P 1$ at 238. The USPTO's motion related to the claims of plaintiffs that the patents at issue violated article I, section 8, clause 8 of the United States Constitution and the First Amendment to the United States Constitution. See Memorandum of Law in Support of Defendant United States Patent and Trademark Office's, Motion for Judgment on the Pleadings and in Opposition to Plaintiffs ‘ Motion for Summary Judgment, 2009 WL 5785024 (S.D.N.Y.), at * 2. For discussions of the decision in AMP1, see Eileen M. Kane, Patenting Genes and Genetic Methods: What's At Stake?, 6 J. Bus. \& TECH. L. 1, 11-18 (2011) [hereinafter Patenting]; Andrew S. Robertson, The Role of DNA Patents In Genetic Test Innovation And Access, 9 Nw. J. TECH. \& INTELL. Prop. 377, at*13-15 ( 2011); Miri Yoon, Gene Patenting Debate: The Meaning Of Myriad, 9 J. MARShall ReV. InTELl. Prop. L. 953 ( 2010) .

${ }^{10} A M P 2,653$ F.3d at 1333, 1354-59. The Federal Circuit also reversed the District Court's decision that one of the methods (screening potential cancer therapeutics) was not patentable but affirmed the District Court's decision that the other method claims (comparing or analyzing DNA sequences) were not patentable. Id. at 1355-58. (Judge Lourie) [hereinafter Majority Opinion]; Id. at 1364-67 (Moore, J., concurring) [hereinafter Concurring Opinion] 
DNA segments constituted patentable subject matter. ${ }^{11}$ The plaintiffs petitioned for a panel rehearing (the "Petition"), and on September 13, the Federal Circuit denied the Petition. In October, the plaintiffs filed a petition for a writ of certiorari with the United States Supreme Court. $^{12}$ In light of the three different opinions and the acknowledgment of the crucial issues involved, ${ }^{13}$ this article recommends the Supreme Court hear the case.

The direct question regarding the product claims is whether isolated DNA segments are patentable under Article I, Section 8, Clause 8 of the United States Constitution (hereafter the "Patent Clause") and 35 U.S.C. $\S 101(\S 101) .{ }^{14}$ The Patent Clause is both a grant of power to and

(concurring on the method claims and noting that the claims to isolated cDNA segments constituted patentable subject matter ; agreeing with the judgment on the other product claims without agreeing with the reasoning of the Majority Opinion on the DNA product claims); Id. at 1373 (Bryson, J., dissenting in part, concurring in part) [hereinafter Dissent] (concurring with the Majority Opinion on the method and cDNA claims, but dissented on the other product claims).

${ }^{11}$ Intervet, Inc. v. Merial, Ltd., 617 F.3d 1282, 1292 (Fed. Cir. 2010 ) (Dyk, J., concurring in part and dissenting in part) (noting that isolated DNA can be defined as a segment of DNA "which is substantially separated from other cellular components which naturally accompany a native human sequence or protein." ). See also infra note 140.

${ }^{12} 2011$ WL 5057016, at*1 (Fed. Cir. Aug. 26, 2011) (arguing in the Petition, "The Court Erred In Failing To Consider Whether The DNA Fragments Claimed In These Patents Are Products Of Nature"); Allison Dobson, Classen: Has the Federal Circuit Lost Interest in Patentable Subject Matter?, GENOMICS LAW REPORT (Sept. 14, 2011), http://www.genomicslawreport.com/index.php/tag/myriad-genetics/ (reporting the denial of the petition for rehearing); Tom Harvey, Utah Firm's Gene Patent Case Could Go To Supreme Court, The Salt LaKe TribunE (Oct. 12, 2011), http://www.sltrib.com/sltrib/money/52711149-79/court-myriad-genes-aclu.html.csp (statement of counsel for plaintiffs of intention to petition the Supreme Court).

${ }^{13}$ In spite of ruling against the plaintiffs in $A M P 2$, the Federal Circuit acknowledged the importance of the issues when it observed the genetic testing at issue "provides a patient with information on her risk for hereditary breast and ovarian cancers, and thus aids in the difficult decision regarding whether to undertake preventive options, including prophylactic surgery. Diagnostic results can also be an important factor in structuring an appropriate course of cancer treatment, since certain forms of chemotherapy are more effective in treating cancers related to BRCA mutations." AMP2, 653 F.3d at 1339.

${ }^{14}$ See infra text accompanying notes 135-139. The answer to this question will of course affect the patentability of other genetic and biological material. See Patenting, supra note 9, at 9 ("The resolution of eligibility for genes has implications for the patenting of other biomolecules. The resolution of eligibility of genetic testing methods has implications for the contours of the preemption analysis as applied to subject matter in the life and physical sciences, an issue that will likely emerge in such fields as nanotechnology."). The Patent Clause provides, "Congress shall have the power ... To promote the Progress of Science and useful Arts, by securing for limited Times to Authors and Inventors the exclusive Right to their respective Writings and Discoveries." ${ }^{14}$ U.S. CONST., ART. I, § 8, cl. 8 (capitalization as in the Constitution). In the Patent Clause, "useful Arts", "Inventors" and "Discoveries" provide the basis for patent statutes and "Science", "Authors" and "Writings" provide the basis for copyright statutes. See, e.g., 1 R. CARL Moy, Moy's Walker on Patents $\$ 1.11$ (4th Ed. 2003); 1 DONald S. Chisum, Chisum On Patents OV-2, OV-3, 1-6 and 1-7. 
a limitation on the power of Congress. ${ }^{15}$ As a result, "Congress may not authorize the issuance of patents whose effects are to remove existent knowledge from the public domain, or to restrict free access to materials already available." ${ }^{16}$ By statute, a person may obtain a patent if she "invents or discovers any new and useful process, machine, manufacture, or composition of matter, or any new and useful improvement," and if the invention meets the other requirements for a patent. ${ }^{17}$

The Supreme Court has cautioned that there are limits to the scope of patentable subject matter under $\S 101,{ }^{18}$ even though the Court has interpreted $\S 101$ expansively and described it as "a dynamic provision designed to encompass new and unforeseen inventions." ${ }^{19}$ The "laws of

\footnotetext{
${ }^{15}$ Graham v. John Deere Company of Kansas City, 383 U.S. 1, 5 (1966). John Deere involved whether a patent for a "Clamp for vibrating Shank Plows" was obvious and therefore invalid. Id. at 4.

${ }^{16} 383$ U.S. at 6 (emphasis added), also citing concurring opinions of Justices Douglas and Black in Great Atl. \& Pac. Tea Co. v. Supermarket Equip. Corp., 340 U.S. 147, 154 (1950) (in which Justices Douglas and Black said that "[t]he Congress does not have free reign, for example, to decide that patents should be easily or freely given. The Congress acts under the restraint imposed by the statement of purpose in Art. I, s 8."). See also, Richard Seth Gipstein, The Isolation And Purification Exception To The General Unpatentability Of Products Of Nature, 4 COlumbia SCI. \& TECH. L. ReV. 1, 7 (2002) (quoting Deere and concluding that "[i]t therefore follows that the invalidation of patents claiming products of nature, which have been deemed by the Supreme Court to be $\rightarrow$ ree to all men and reserved exclusively to none," ... is constitutionally mandated. There need not be any statutory authority to deny patents that claim products of nature.").

${ }^{17} 35$ U.S.C. $\$ 101$ (2006).

${ }^{18}$ Diamond v. Chakrabarty, 447 U.S. 303, 309 (1980) ("This is not to suggest that $\S 101$ has no limits or that it embraces every discovery."); Bilski v. Kappos, 130 S. Ct. 3218, 3225 (2010) ("The Court's precedents provide three specific exceptions to $\S 101$ 's broad patent-eligibility principles."). The current four categories in $\S 101$ (process, machine manufacture and composition of matter) are essentially the same categories that have been capable of being patented since the passage of the first patent statute in 1790. In 1790, the statutory categories were "any useful art, manufacture, engine, machine, or device, or any improvement thereon not before known or used." Chisum, supra note 16, at OV-2, OV-3, 1-6, 1-7. In 1793, the categories were amended to "any useful art, machine, manufacture or composition of matter, or any new and useful improvement, not known or used before the application." Id. In 1952, Congress replaced "art" with "process", but stated that process meant "process, art or method." Id. In addition to the requirements in $\S 101$, in order for an invention to be patentable, the invention must be novel within the meaning of $\S 102$ (a) and not obviousness within the meaning of $\S 103$ ), and the application must contain disclosures about the invention that satisfy the requirements of $\$ 112$. Regardless of whether or not the claimed invention meets the other criteria for a patent, an individual cannot obtain a patent unless the invention "falls within one of the express categories of patentable subject matter of 35 U.S.C. §101." Kewanee Oil v. Bicron Corp., 416 U.S. 470, 483 (1974).

${ }^{19}$ J.E.M. Ag Supply, Inc. v. Pioneer Hi Breed Intern., Inc., 534 U.S. 124, 135, 145 (2001) (holding "that newly developed plant breeds fall within the terms of §101."). The Supreme Court has defined "manufacture" broadly as the production of articles for use from raw or prepared materials by giving to these materials new forms, qualities, properties, or combinations, whether by hand-labor or by machinery." Chakrabarty, 447 U.S. at 308 (quoting
} 
nature", "physical phenomena" and "abstract ideas" are limited as not patentable subject matter. ${ }^{20}$

Professor Kane has explained, "The underlying rationale for the exclusions is that scientific advances depend on an available substrate of basic knowledge, and that, therefore, patenting the intellectual foundations of a field has an adverse effect on its progress." ${ }^{21}$ What may be a "process," a "composition of matter," or a "manufacture" in the ordinary meaning of those terms is not patentable subject matter if the proposed patent claims a law of nature, a physical phenomenon, or an abstract idea. ${ }^{22}$

The Supreme Court has not defined "physical phenomena," but gave relevant examples of unpatentable subject matter. In Diamond v. Chakrabarty, the Court said the following examples

\footnotetext{
American Fruit Growers, Inc. v. Brogdex Co., 283 U.S. 1, 11 (1931)). The Court has defined "composition of matter" very broadly as including all compositions of two or more substances and . . . all composite articles, whether they be the results of chemical union, or of mechanical mixture, or whether they be gases, fluids, powders or solids." Chakrabarty, 447 U.S. at 308 (quoting Shell Dev. Co. v. Watson, 149 F.Supp. 279, 280 (D.C.1957)). The Court noted that a Senate committee report on the 1952 Patent Act had said, "Congress intended statutory subject matter to 'include anything under the sun that is made by man," but the Supreme Court clearly meant that general statement was limited by the principle the Court repeated in Chakrabarty, 447 U.S. at 309, that the laws of nature, physical phenomena, and abstract ideas are not patentable, because they are not made by humans. Chakrabarty, 447 U.S. at 309. For positions that the quote from the Senate Committee report was more limited when considering the context, see Bilski, $130 \mathrm{~S}$. Ct. at 3248-49 (Stevens, J., concurring); Oskar Liivak, The Forgotten Originality Requirement: A Constitutional Hurdle for Gene Patents, 87 J.PAT. \& TRADEMARK OfF. SOC'Y 261, 279-281 (2005); MoY, supra note 14, at 5-8 ("while both Congress and the courts have stated that the statutory language of section 101 encompasses 'anything under the sun that is made by man,' ... this is decidedly not the case. Instead, the authorities have agreed that certain types of activity are non-statutory subject matter, even where the particular subject matter at hand could be described nominally in the terms of section 101 as, for example, a process or an article of manufacture.").

${ }^{20}$ Chakrabarty, 447 U.S. at 309 (citing Parker v. Flook, 437 U.S. 584 (1978); Gottschalk v. Benson, 409 U.S. 63,67 (1972); Funk Bros. Seed Co. v. Kalo Inoculant Co., 333 U.S. 127, 130 (1948); O`Reilly v. Morse, 15 U.S. 65, $112-$ 121 (1854); and Le Roy v. Tatham, 55 U.S. 156, 175 (1853)). See also Bilski, 130 S. Ct. at 3225 (referring to the three exceptions to patentable subject matter under $\$ 101$ as "laws of nature, physical phenomena and abstract ideas."). In Diamond v. Diehr, 450 U.S. 175, 185 (1981), the Court referred to "natural phenomena" as unpatentable; in Benson, 409 U.S. at 67, the Court referred to "Phenomena of nature" as unpatentable; and in Parker, 437 U.S. at 589, the Court referred to "Phenomena of nature" as unpatentable. The Court appears to use those terms interchangeably, but since the Court in Bilski - the most recent decision - and in Chakrabarty to "physical phenomena" as the third exception to patentable subject matter, this article generally uses "physical phenomena."

${ }^{21}$ Kane, supra note 9 , at $4-5$.

${ }^{22}$ See Bilski, 130 S. Ct. at 3226 ("Any suggestion in this Court's case law that the Patent Act's terms deviate from their ordinary meaning has only been an explanation for the exceptions for laws of nature, physical phenomena, and abstract ideas."). In Bilski, the Supreme Court limited the meaning of "process" to avoid the issuance of a patent for an abstract idea. Id. at 3229-31.
} 
did not constitute patentable subject matter: a new mineral discovered in the earth, a new plant found in the wild, Einstein's "law" of relativity, and the "law" of gravity discovered by Newton. ${ }^{23}$ In Parker v. Flook, in dissenting on whether the process at issue was patentable, the Chief Justice and Justices Stewart and Rhenquist said, "A patent could not issue, in other words, on the law of gravity, or the multiplication tables, or the phenomena of magnetism, or the fact that water at sea level boils at 100 degrees centigrade and freezes at zero-even though newly discovered." ${ }^{24}$ In Funk Brothers Seed Co. v. Kalo Inoculant Co., the Court said, "The qualities of these bacteria, like the heat of the sun, electricity, or the qualities of metals, are part of the storehouse of knowledge of all men. They are manifestations of laws of nature, free to all men, and reserved exclusively to none.""'25

The common definition of "phenomenon" is "an occurrence or fact that is perceptible by; the senses," and absent any statutory definition, the Supreme Court relies on the common understanding and definition of a word for its meaning. ${ }^{26}$ Certainly some of the examples given by the Justices are abstract ideas (e.g., multiplication tables) and laws of nature (e.g., the law of relativity), but others are physical phenomena (e.g., magnetism and electricity) within the common understanding of the phrase. ${ }^{27}$ Comparing the "observable occurrences" of a claimed

\footnotetext{
${ }^{23}$ Chakrabarty, 447 U.S. at 309. For a more complete discussion of Chakrabarty, see discussion infra Part III.B.3.

${ }^{24}$ Parker, 437 U.S. at 598-599 (The majority did not disagree with those examples).

${ }^{25} 333$ U.S. at 130.

${ }^{26}$ See The American Heritage Dictionary (4th ed.2006). Similarly, Merriam-Webster defines phenomena as "an observable fact or event." See MERRIAM-WEBSTER DICTIONARY http://www.merriamwebster.com/dictionary/phenomenon (last visited 8/28/2011). For the Supreme Court's general reliance on dictionary definitions and common understandings of words, see Chakrabarty, 447 U.S. at 308, and Bilski, $130 \mathrm{~S}$. Ct. at 3226 .

${ }^{27}$ See e.g., The American Heritage Dictionary (4th ed. 2006) (defining "electricity" as, "The physical phenomena arising from the attraction of particles with opposite charges and the repulsion of particles with the same charge." and "magnetism" as "The properties and effects associated with a magnetic field."). See also MERRIAMWEBSTER DiCTIONARY (2011) http://www.merriam-webster.com/dictionary/magnetism (last visited Aug. 14, 2011) (defining magnetisim as "a class of physical phenomena that include the attraction for iron observed in lodestone
} 
invention with those of the natural analog of the invention is one test the courts consistently follow in construing whether an invention constitutes patentable subject matter (but the Federal Circuit rejected that consideration in $A M P 2) .{ }^{28}$

This article argues that the Federal Circuit was wrong in $A M P 2$ for three basic reasons. First, although humans developed the process of isolating DNA segments, and such processes can be patentable subject matter, ${ }^{29}$ humans did not originally develop either the nucleotides or the sequence of nucleotides, nor did humans create the coding of the proteins. The isolated DNA segments of claim 1 are not patentable subject matter, because the characteristics and uses of those segments are not markedly different from the analogous native DNA segments, the test for patentable subject matter under Chakrabarty. ${ }^{30}$

Second, isolated DNA segments "coding for a BRCA1 polypeptide" constitute unpatentable physical phenomena, just as magnetism and electricity are unpatentable phenomena. $^{31}$ Indeed, product claim 1 expressly claims not "simply" one nucleotide sequence, but the phenomena - and thus all the sequences - - eoding for a BRACA1 polypeptide, said polypeptide having the amino acid sequences set forth in SEQ ID No:2." 32 In turn, by definition claim 1 does not include any sequences that do not code for the BRCA1 polypeptide -- it simply claims the physical phenomena, which the Supreme Court said constitutes unpatentable subject

and a magnet, are inseparably associated with moving electricity, are exhibited by both magnets and electric currents, and are characterized by fields of force.").

${ }^{28}$ See infra Parts II.A, II.B, III.B.2. See also sources cited supra note 10.

${ }^{29}$ Chakrabarty, 447 U.S. at 313 (explaining that "Congress ... recognized the relevant distinction [between patentable and unpatentable subject matter] was not between living and inanimate things, but between products of nature, whether living or not, and human-made inventions.").

${ }^{30}$ See infra Part III.B.3.

${ }^{31}$ Chakrabarty, 447 U.S. at 309.

${ }^{32}$ AMP2, 653 F.3d at 1334. See also Jeffrey A. Lefstein, The Formal Structure Of Patent Law And The Limits Of Enablement, 23 BERKELEY TECH. L.J. 1141, 1168 ( 2008) (explaining "because multiple DNA molecules can encode the same polypeptide, an inventor discovering a novel protein will typically claim the genes of all DNA molecules encoding that protein."). 
matter. Unfortunately the majority opinion rejected any consideration of the phenomena of the DNA segments. ${ }^{33}$

Third, both the majority opinion and concurring opinion argue that (1) it is significant the USPTO has granted patents on isolated DNA segments for years and (2) patentable subject matter under $\S 101$ is expansive. Although patentable subject matter under $\S 101$ is expansive, the courts have made clear that physical phenomena, laws of nature and abstract ideas are boundaries over which patentable subject matter does not trespass. The courts established these boundaries, and the USPTO has no special expertise in interpreting them. Indeed, the USPTO was wrong for years in granting business method patents for "processes" under a lax standard that the Supreme Court subsequently rejected as an unpatentable abstract idea. ${ }^{34}$ Moreover, recently the United States has essentially disavowed the past practices of the USPTO with respect to isolated DNA segments, as discussed in part IIC2 below. ${ }^{35}$

Part II of this article provides a history of cases on patentable subject matter and related topics, much of which history the majority opinion and concurring opinion ignore. ${ }^{36}$ Part III ${ }^{37}$

\footnotetext{
${ }^{33} A M P 2,653$ F.3d at 1353. Would claim 1 have constituted patentable subject matter if Myriad had revised claim 1 to list the many different nucleotide sequences that code for the BRCA1 polypeptide rather than defining the subject matter as base sequences that code for the BRCA1 polypeptide? First, the analysis in that situation would still have to consider- under Chakrabarty - whether the characteristics and uses of the claimed invention would have been markedly different than the native sequences. The reasoning in IVA4 and IVA5 of this article might argue that the characteristics and uses would still not be markedly different, so the revised claim would still constitute unpatentable subject matter, regardless of whether or not the claim constituted unpatentable physical phenomena. Second, even if this analysis concluded the revised claimed subject matter was markedly different from the native DNA segments, the analysis should separately consider whether claiming the listed sequences rather than pre-empted the physical phenomena and thus remained unpatentable subject matter. For the seminal article that the isolated DNA would preempt the physical phenomena and be unpatentable subject matter, see Eileen M. Kane, Splitting the Gene: DNA Patents and the Genetic Code, 71 TENN. L. REV. 707, 709 (2004). [hereinafter Splitting].

${ }^{34}$ Bilski v. Kappos, 130 S. Ct. 3218, 3229-30 (2010).

${ }^{35}$ See infra text accompanying notes 225-228.

${ }^{36}$ See discussion infra Part II. This history both supports the conclusion that the isolated DNA segments are not patentable subject matter and suggests that the argument of the Majority Opinion and Concurring Opinion that expectations were that isolated DNA segments were patentable were not based on fact. This article does not concede, however, that whatever expectations may have resulted from USPTO actions is relevant.

${ }^{37} A M P 2,653$ F.3d at 1339.
} 
discusses the representative patents and critiques the majority opinion and concurring opinion in AMP2, based on the dissent and cases discussed in Part III. Part III also shows there is no policy reason for the Supreme Court in this case to narrow its prior precedents. Part IV gives concluding observations, and there is an Appendix that summarizes basic scientific knowledge about DNA, genes, RNA and related matters, largely from discussions in AMP1, AMP2 and textbooks. $^{38}$

\section{WHAT IS NOT PATENTABLE}

\section{A. Product of Nature Doctrine in the Nineteenth Century}

\section{Nineteenth century cases}

Since the elements of patentability for inventions have stayed strikingly similar since 1790 , nineteenth century patent decisions involving nature and natural forces remain relevant to the issues in $A M P 1$ and $A M P 2$. In 1841, for instance, in In re Kemper, the D.C. Circuit rejected a patent claim for an improvement in the manner of stowing ice. ${ }^{39}$ Rejecting the patent claim, the court said it was "the discovery of a fact which existed long before . . . that ice placed edgewise kept longer than when placed flatwise. This is a mere naked discovery, for which a patent cannot be granted."

The court in Morton v. New York Eye Infirmary expressly addressed the question of

\footnotetext{
${ }^{38} I d$. at 1335, n. 1 ("The district court's opinion ... contains a detailed and comprehensive discussion of the science involved in this case. We repeat only the basics here."). This article therefore assumes that there were no disagreements on the facts between the decisions in $A M P 1$ and $A M P 2$ on claim 1, so this article cites discussions of the science pertaining to DNA and related matters from both $A M P 1$ and $A M P 2$. AMP2 has some very helpful diagrams on DNA that any reader not immersed in the science of DNA may want to review. See AMP2, 653 F.3d at 1335-36, figures 1-4.

${ }^{39}$ In re Kemper, 14 F. Cas. 286, No. 7687 (C.C. D.C. 1841).

${ }^{40} I d$. at 288 (emphasis added).
} 
whether "the subject matter of the alleged invention [is] patentable?" ${ }^{41}$ The court concluded the answer is no, since "[w]e have, after all, only a new or more perfect effect of a well-known chemical agent, operating through one of the ordinary functions of animal life." ${ }^{2}$ In a conclusion that still should have relevance today, the court said, "Neither the natural functions of an animal upon which or through which it may be designed to operate, nor any of the useful purposes to which it may be applied, can form any essential parts of the combination [constituting the claimed invention], however they may illustrate and establish its usefulness." 43

In 1874 in American Wood Paper Co. v. Fibre Disintegrating Co., the Supreme Court held that a patent involving a substance found in nature is invalid because it is not novel. ${ }^{44}$ Specifically, the patent claim was for - a new article of manufacture, ... a pulp suitable for the manufacture of paper, made from wood or other vegetable substances, by boiling or other vegetable substance in alkali under pressure, substantially as described."45 The Court said, There are many things well known and valuable in medicine or in the arts which may be extracted from diverse substances. But the extract is the same, no matter from what it has been

\footnotetext{
${ }^{41}$ Morton v. New York Infirmary, 17 F. Cas. 879, 882 (C.C.S.D.N.Y. 1862) (No. 9,865) (the patent was for the use of ether for surgery on animals; specifically that "this well-known inhalation of well-known agents (in increased [sic] quantities) would produce a state of the animal analogous to complete intoxication accompanied with total insensibility to pain.").

${ }^{42} I d$. at 883 .

${ }^{43} I d$. at 884 (emphasis added) (explaining "A discovery may be brilliant and useful, and not patentable. No matter through what long, solitary vigils, or by what importunate efforts, the secret may have been wrung from the bosom of Nature, or to what useful purpose it may be applied. Something more is necessary. The new force or principle brought to light must be embodied and set to work, and can be patented only in connection or combination with the means by which, or the medium through which, it operates.").

${ }^{44}$ Am. Wood Paper Co. v. Fibre Disintegrating Co., 90 U.S. 566 (1874).

${ }^{45} I d$. at 577. Since the patent claim discussed the process by which the claimed product was produced, the claimed patent might be described as a type of "product by process claim." See Cochrane v. Badische Anilin \& Soda Fabrik, 111 U.S. 293, 310 (1884) ("Every patent for a product or composition of matter must identify it so that it can be recognized aside from the description of the process for making it, or else nothing can be held to infringe the patent which is not made by that process."); Atlantic Thermoplastics Co., Inc. v. Faytex Corp., 970 F.2d 834, 841-42, 84647 (Fed. Cir. 1992) ("process terms in product-by-process claims serve as limitations in determining infringement."). But see American Wood Paper, 90 U.S. at 593, 596-607 (there was separately a process claim at issue).
} 
taken. ${ }^{26}$ The Court concluded that the product found in nature, cellulose, previously had been obtained from other products, such as straw, wood and other vegetable substances, so "whatever may be said of their process for obtaining it, the product was in no sense new. The reissued patent . . . is, therefore, void for want of novelty." ${ }^{47}$

Regardless of whether the invention in American Wood Paper was directly made from a -natural" product (all manufactures at some level arise from nature), ${ }^{48}$ the case involved a comparison of a building block in nature - cellulose - with the claimed patented product. ${ }^{49}$ The holding on lack of novelty is consistent and interchangeable with the argument that building blocks of nature are not patentable, either because building blocks of nature are not patentable subject matter or because manmade copies of them are not new.

In Cochrane v. Badische Anlin and Soda Farik, a case involving a patent for an "improvement in dyes or coloring matter from anthracine," ${ }^{15}$ the Supreme Court first analyzed the claim as a product by process claim and said, "[U]nless it is shown that the process of No.

\footnotetext{
${ }^{46}$ American Wood Paper, 90 U.S. at 593. The Court added $\left.\mathrm{fw}\right]$ hether a slight difference in the degree of purity of an article produced by several processes justifies denominating the products different manufactures, so that different patents may be obtained for each, may well be doubted, and it is not necessary to decide.". Id. at 594.

${ }^{47} I d$. at 596 . The Court also observed that "[t]he substance of the products, therefore, was the same, and so were their uses. The design and the end of their production was the same, no matter how or from what they were produced.". Id. at 594.

${ }^{48}$ In Funk Bros., Justice Frankfurter concurred with the result, but said, "[i]t only confuses the issue, however, to introduce such terms as the work of nature' and the laws of nature." .... Everything that happens may be deemed the work of nature, ' and any patentable composite exemplifies in its properties the laws of nature." 333 U.S. 127, 134-35 (Frankfurter, J., concurring) (Of course that statement is true in one sense, but lightening would more easily be accepted as a direct work of nature than the light emanating from a light bulb, which is a product of humans that take into account the laws of nature.).

${ }^{49}$ John M. Conley \& Roberte Makowski, Back to the Future: Rethinking the Product of Nature Doctrine as a Barrier to Biotechnology Patents (Part I), 85 J. PAT. \& TRADEMARK OFF. SOC'Y 301, 328 n. 193 (2003) (Conley and Makowski say American Wood Paper was —at really [a] product of nature case.... [but] involved a substance previously derived from other commercial processes.").

${ }^{50}$ Cochrane v. Badische Anilin \& Soda Fabrik, 111 U.S. 293, 294 (1884) The Court said "[t]he claim of No. 4,321 is as follows: Artificial alizarine, produced from anthracine or its derivatives by either of the methods herein described, or by any other method which will produce a like result." Id. at 296. And also "Anthracene is one of a group of chemicals called polycyclic aromatic hydrocarbons, PAHs for short. .... Like most PAHs, anthracene is used to make dyes, plastics and pesticides."). Id.; See also Anthrazine Fact Sheet at www.epa.gov/osw/hazard/wastemin/minimize/factshts/anthrace.pdf (last visited June 11, 2011).
} 
4,321 was followed to produce the defendant's article, or unless it is shown that that article could not be produced by any other process, the defendant ${ }^{\star} \mathrm{s}$ article cannot be identified as the product of the process of No. 4,321." ${ }^{51}$ The Court determined that the allegedly infringing product had not been produced by the specific process identified in the patent. ${ }^{52}$ The Court then addressed "another view of the case," that "the article ... was an old article." 53 The Court concluded, "calling it [the invention] artificial alizarine did not make it a new composition of matter ${ }^{54}$

Two additional nineteenth century patent cases also suggest that mankind cannot patent natural forces, at least without tying those forces to some useful mechanism that result in the force operating differently than it operates in nature. ${ }^{55}$ In Dolbear v. American Bell Telephone Co., the Supreme Court upheld Alexander Graham Bell's invention of the telephone, even though it used electricity, one of the forces of nature. ${ }^{56}$ The Court explained, "electricity, left to itself, will not do what is wanted. The art consists in controlling the force [of nature] as to make it accomplish the purpose." ${ }^{57}$ The patent was valid, the Court explained, because "the claim is not for the use of a current of electricity in its natural state as it comes from the battery, but for putting a continuous current in a closed circuit, into a certain specified condition, suited to the transmission of vocal and other sounds, and using it in that condition for that purpose." ${ }^{58}$ Of

\footnotetext{
${ }^{51}$ Cochrane, 111 U.S. at 310 (The Court continued that "the product itself could not be patented, even though it was a product made artificially for the first time, in contradistinction to being eliminated from the madder root.").

${ }^{52} I d$. at 311.

${ }^{53} I d$.

${ }^{54}$ Id. Compare Conley \& Mackowski, supra note 49 at 328, n. 193, (refering to this view of the case as "effectively dictum.") with 111 U.S. at 313 (in which the Court did not choose between the two views of the case when it stated that, "In either view the decree of the circuit court must be reversed," indicating neither view was dictum

${ }^{55}$ See Efthimios Parasidis, A Uniform Framework For Patent Eligibility, 85 Tul. L. Rev. 323, 370 ( 2010) (explaining one of these two cases - O'Reilly v. Morse - and saying, "to the extent a patent claim applies a natural principle to some specific end, the claim is eligible for patent consideration as long as the claim does not preempt all practical uses of the natural principle.").

${ }^{56}$ Dolbear v. Am. Bell Tel. Co., 126 U.S. 1, 8 S. Ct. 778, 781 (1888).

${ }^{57} I d$.

${ }^{58} I d$. at 783 .
}

PGH. J. TeCh. L. \& POL'Y, Vol. 12, No. 3, Fall 2011 
course, in nature electricity does not arise from a battery. The reference to "from the battery" in American Bell suggests that even when electricity is removed, or isolated, from its natural state, it was not patentable unless the inventor changed how the force - electricity - operated. ${ }^{59}$

The Supreme Court upheld Samuel Morse's invention of the telegraph in O'Reilly $v$. Morse $^{60}$ but rejected his claim for the "use of the motive power of the electric or galvanic current .. electro-magnetism." 61 In American Bell, the Court explained that the effect of Morse was "that the use of magnetism as a motive power, without regard to the particular process with which it was connected in the patent, could not be claimed, but that its use in that connection [a specified mechanical process] could." 62 Although the Court said, "the [eighth] claim is too broad,"63 in the immediately following paragraph the court explained, "No one, we suppose will maintain that Fulton could have taken out a patent for his invention of propelling vessels by steam, describing the process and machinery he used, and claimed under it the exclusive right to use the motive power of the steam."

The Court in Morse did not simply say there was a problem with the way the inventor wrote the eighth claim. The Court indicated patents cannot capture physical phenomena such as electro-magnetism, in contrast to a machine that makes use of electro-magnetism. ${ }^{64}$

\footnotetext{
${ }^{59}$ Of course, that statement about "from the battery" was dicta, but since $A M P 1$ and $A M P 2$ are the first cases in which a court has directly ruled on the patentability of isolated DNA segments, it is appropriate to look at related situations, although they are not holdings.

${ }^{60} \mathrm{O}$ 'Reily v. Morse, 56 U.S. 62 (1853).

${ }^{61} I d$. at 86 ("Eighth. I do not propose to limit myself to the specific machinery, or parts of machinery, described in the foregoing specifications and claims; the essence of my invention being the use of the motive power of the electric or galvanic current, which I call electro-magnetism, however developed, for making or printing intelligible characters, letters, or signs, at any distances, being a new application of that power, of which I claim to be the first inventor or discovered.").

${ }^{62}$ Dolbear, 8 S. Ct. at 782.

${ }^{63} O^{\prime}$ Reily, 56 U.S. at 113.

${ }^{64}$ See Jay Dratler, Jr., Alice In Wonderland Meets The U.S. Patent System, 38 AKron L. ReV. 299, 323 (2005) (suggesting that Morse was more than simply a disclosure case: "how much coverage should a patent give a legitimate inventor who properly discloses what his invention is and how it works? Provide too little coverage and
} 
In Wall v. Leck, the Ninth Circuit ruled invalid a claim for the process of fumigating trees and plants in the absence of light. ${ }^{65}$ The court explained, "No natural function of the day or of the night, of the sun or of the moon, is patentable. These natural conditions are as free to all mankind as is the air we breathe." ${ }^{66}$ The court added, "A principle, considered as a natural physical force, is not the product of inventive skill. It is the common property of all mankind. It exists in nature independently of human effort, and can neither be diminished nor increased by human power." 67

\section{Summary of nineteenth century cases}

What do these nineteenth century cases suggest about the patentability of products? They reflect a general understanding of the courts that patents could not issue for products that previously existed in nature, without necessarily identifying whether the product was new or the subject matter was unpatentable. ${ }^{68}$ The cases also reflect a general understanding that patents could not issue for natural forces, such as magnetism, whether called natural or physical phenomena. To avoid taking these cases into account would lead to the mistaken conclusion that the courts had expansively interpreted $\S 101$ and patentable subject matter without limits.

In AMP2 the majority opinion only mentions Cochrane and American Wood Paper of the above cases and dismisses them by saying, "Other Supreme Court decisions cited by the parties

patents can be circumventable and therefore become devalued or worthless. Provide too much and you will thwart further progress in technology, as well as -inenting around," and the patentee will receive a windfall.").

${ }^{65}$ Wall v. Leck, 66 F. 552, 553-54 (9th Cir. 1895).

${ }^{66} I d$. at 557.

${ }^{67} I d$.

${ }^{68}$ Referring to Tatham, Morse, American Bell Tel. and a nineteenth century English patent case, Professor Parasidis says, "these early opinions dictate that a natural principle, in and of itself, is ineligible for patent protection because it may never be deemed to be new under the terms of the statute." Parasidis, supra note 55,at 340. 
and amici were decided based on lack of novelty, not patentable subject matter." ${ }^{69}$ While it is true the Court rejected the patent claims in American Wood Paper due to lack of novelty, when the Supreme Court decided these cases, novelty and subject matter were part of the same statute. ${ }^{70}$ Also, the Court in noted in Cochrane, "Calling it artificial alizarine did not make it a new composition of matter." ${ }^{71}$ It is not clear the Supreme Court in either case was distinguishing between lack of novelty and an unpatentable composition of matter.

\section{B. Modification of Nature in the Twentieth Century}

In the twentieth century, the Supreme Court addressed the patentability of products in which the inventors had claimed they changed nature in significant ways to create patentable inventions. Yet none of them hold or suggest that an inventor can patent a natural force - such as the coding properties of DNA segments - that operates through the invention in the same way as it operates in nature.

\section{American Fruit Growers, Inc.}

In American Fruit Growers, Inc. v. Brogdex Co., the Supreme Court addressed a product patent for "[f]resh citrus fruit of which the rind or skin carries borax in amount that is very small but sufficient to render the fruit resistant to blue mold decay." ${ }^{72}$ The issue was whether the claimed product was an article of manufacture. The Court concluded the fruit was not an article

\footnotetext{
${ }^{69}$ See AMP2, 653 F.3d at 1350, n. 6.

${ }^{70}$ Yoon, supra note 9, at 960 ("A major change in the Patent Act of 1952 was the codification of conditions for patentability--novelty under section 102 and nonobviousness under section 103. Prior to the Patent Act of 1952, the inquiry for patent eligible subject matter was intertwined with the inquiry for patentability.").

${ }^{71}$ See infra text accompanying notes 50-54. The Court earlier in the decision noted that "The answer also avers that alizarine is a natural product, having a well-known definite constitution; that it is not a composition of matter, within the meaning of the statute, but has been well known in the arts, from time immemorial."' 111 U.S. at 297.

${ }^{72} 283$ U.S. 1, 6 (1931). There was also a process claim involved in the opinion, and the process claim was rejected on the basis of lack of novelty. Id. at 6, 13. Brogdex Co. had sued American Fruit Growers, Inc. ("AFG") for shipping citrus fruit in violation of Brogdex Co.'s patent, and AFG admitted dipping the citrus fruit "in a borax solution in order to prevent or retard decay incident to growth of blue mold." $I d$. at 10 .
} 
of manufacture, because it did not possess "a new or distinctive form, quality or property." ${ }^{73}$ The Court cited two tariff cases on the meaning of an article of manufacture, and said, "There must be transformation; a new and different article must emerge 'having a distinctive name, character, or use."'174

The Supreme Court in American Fruit Growers rejected the analysis of the court of appeals that the product patent was valid because the complete article was not found in nature. ${ }^{75}$ The Court explained, "The added substance only protects the natural article against deterioration by inhibiting development of extraneous spores upon the rind. There is no change in the name, appearance, or general character of the fruit. It remains a fresh orange, fit only for the same beneficial uses as theretofore." ${ }^{76}$

In other words, in concluding that the patent claim did not recite an article of manufacture, the Supreme Court considered two issues: the composition of the purported article of manufacture (an orange with borax inserted in the rind/skin) and the "beneficial uses" of the orange without borax added and with borax added. The fact that the borax allowed the orange to stay fresh for a longer time than the natural article did not cause sufficient change to the orange to cause the orange with borax to constitute an article of manufacture.

\section{Funk Brothers Seed Co.}

In 1948, the Supreme Court directly addressed patentable subject matter and products of

\footnotetext{
${ }^{73}$ Id. at 11 .

${ }^{74}$ Id. at 13 (citing Anheuser-Busch Brewing Ass'n v. United States,. 207 U.S. 556, 562 (1908) and Hartranft v. Wigemann, 212 U.S. 609, 613, 617 (1887)).

${ }^{75} 283$ U.S. at 11.

${ }^{76}$ Id. at 11-12. See Patenting, supra note 9, at 13 ("the Supreme Court decided that the addition of borax to the rind of an orange to increase its longevity did not confer a patentable distinction, when compared to an unadulterated orange, to create an article of manufacture.").
} 
nature in Funk Brothers Seed Co. v. Kalo Inoculant Co. ${ }^{77}$ Kalo Inoculant had sued Funk Bros. for infringement of Kalo Inoculant's patent for an inoculant ${ }^{78}$ of bacteria for leguminous plants, and Funk Brothers responded that the patent was invalid. ${ }^{79}$

Different Rhizobium bacteria promoted growth in different legumes, but when mixed together, the experience of mixing different bacteria inhibited the positive growth effects of each other on the legumes. ${ }^{80}$ Bond, the inventor, however, determined certain bacteria could be mixed together without the inhibiting effect, and he provided to the public a mixture of certain bacteria for use with several different species of legumes. ${ }^{81}$ The Supreme Court rejected the conclusions of the circuit court that the inventor (1) "did much more than discover a law of nature" and (2) "made a new and different composition of non-inhibitive strains which contributed utility and economy to the manufacture and distribution of commercial inoculants." 82

Referring to the bacteria, the Supreme Court concluded, "Their qualities are the work of nature. Those qualities are of course not patentable." ${ }^{83}$ It is apparent the qualities of the bacteria the Court was considering were the external effects of the bacteria (not the composition of the bacteria), since the Court explained, "Bond does not create state of inhibition or of non-inhibition

\footnotetext{
${ }^{77} 333$ U.S. 127 (1948). The issue in Funk Bros. was not "whether the methods of selecting and testing the noninhibitive strains are patentable. We have here only product claims." Id. at 130.

${ }^{78}$ "Inoculation is the process of introducing commercially prepared rhizobia bacteria into the soil" to promote nitrogen fixation. "Legumes have the unique ability to form a symbiotic relationship with rhizobia (Rhizobium and Bradyrhizobium) bacteria to convert atmospheric nitrogen gas to ammonia nitrogen, a form usable by the plant. This relationship occurs in specialized root tissue called nodules." Examples of legumes are alfalfa and soybeans. See Colorado State University Fact Sheet on Legume Seed Inoculants, http://www.ext.colostate.edu/pubs/crops/00305.html (last visited Oct. 7,,2011).

${ }^{79}$ What the Court described as illustrative was the following claim: "An inoculant for leguminous plants comprising a plurality of selected mutually non-inhibitive strains of different species of bacteria of the genus Rhizobium, said strains being unaffected by each other in respect to their ability to fix nitrogen in the leguminous plant for which they are specific." Funk Bros., 333 U.S. at 127, n. 1.

${ }^{80} I d$. at 129.

${ }^{81} I d$. Whether or not the process for selecting and testing non-inhibitive strains was patentable was not an issue in the case. Id. at 130 .

${ }^{82}$ Id.at 130-31. See Funk Bros. Seed Co. v. Kalo Inoculant Co., 161 F.2d 981, 986 (7th Cir. 1947).

${ }^{83} 333$ U.S. at 130.
} 
in the bacteria." 84 The Court added, "The qualities of those bacteria, like the heat of the sun, electricity, or the qualities of metals, are part of the storehouse of knowledge of all men" and added they were "manifestations of laws of nature, free to all men and reserved exclusively to none." 85

Funk Brothers supports the principle that in determining whether a composition is patentable subject matter, a court must consider not only the material in the composition but also the effect of that composition, such as the qualities of inhibition and non-inhibition of the bacteria $^{86} \mathrm{~A}$ claim to a force of nature manifested in its natural way in a physical object constitutes an unpatentable phenomenon. ${ }^{87}$

As the Supreme Court in Funk Brothers explained, "The combination of species produces no new bacteria, no change in the six species of bacteria, and no enlargement of the range of their utility. Each species has the same effect it always had. The bacteria perform in their natural way." ${ }^{88}$ Both composition and function of the claimed subject matter are relevant to determining patentable subject matter.

${ }^{84} I d$.

${ }^{85} I d$.

${ }^{86}[\mathrm{~T}] \mathrm{o}$ "take nitrogen form the air and fix it in the plant for conversion to organic nitrogenous compounds" needed for the growth of the plant. Id. at 128-30.

${ }^{87} I d$. at 130 ("He who discovers a hitherto unknown phenomenon of nature has no claim to a monopoly of it"). The Supreme Court also concluded "that the product claims do not disclose an invention or discovery within the meaning of the patent statutes," Id. at 132. This statement seems to refer to the principle that a machine or manufacture that takes into account a law of nature or physical phenomenon can still constitute patentable subject matter, if hte phenomenon is no longer acting in its natural way. See Conley \& Makowski, supra note 49, at 334 (Bond [the inventor] failed because his real and only discovery was the product of nature, which he applied in the most obvious way possible: exactly as he found it. In other words, his patent was denied because his purported application ' was not materially distinguishable from the work of nature.").

${ }^{88} 333$ U.S. at 131. See also Patenting, supra note 9, at 13-14 ("The inventor's focus on the natural non-inhibition actually worked to deny a patent....The Court's decision also described the inventor's work as the 'discovery of some of the handiwork of nature."'). There is disagreement on the holding in Funk Bros., as Professors Conley Makowski discuss in Conley \& Makowski, supra note 49, at 333 ("the case can be plausibly read as turning not so much on the involvement of a product of nature as on the inventor's failure to apply the - wrk of nature" in an non-obvious way." (citing Chisum, supra note 14, at 1-43)). For what Professors Conley and Makowski believe is the "fairer characterization" of Funk Bros., see infra text accompanying note 132. 


\section{Chakrabarty}

In a five to four decision in Diamond v. Chakrabarty, the Supreme Court ultimately held that a live, "human-made" micro-organism (a type of bacterium not occurring in nature because of insertion into the bacteria by humans of four plasmids) constituted patentable subject matter. ${ }^{89}$ The sole issue in Chakrabarty was whether the bacteria constituted patentable subject matter. ${ }^{90}$

The Supreme Court said it "must determine whether respondent's micro-organism constitutes a 'manufacture' or 'composition of matter' within the meaning of the statute."91 The Court first recognized broad definitions of "manufacture" 92 and "composition of matter," ${ }^{93}$ but at the same time recognized limits to patentable subject matter. Specifically, the Court stated,

The laws of nature, physical phenomena, and abstract ideas have been held not patentable .... Thus, a new mineral discovered in the earth or a new plant found in the wild is not patentable subject matter. Likewise, Einstein could not patent his celebrated law that $\mathrm{E}=\mathrm{mc}^{2}$; nor could Newton have patented the law of gravity. ${ }^{94}[$ S] uch discoveries are manifestations of . . . nature, free to all men and

\footnotetext{
${ }^{89}$ Diamond, 447 U.S. at 305. See also In re Bergy, 596 F.2d 952, 968-971 (C.C.P.A. 1979) (discussing the facts in Chakrabarty). The product claim in Chakrabarty was for a bacterium from the genus Pseudomonas containing therein at least two stable energy-generating plasmids, each of said plasmids providing a separate hydrocarbon degradative pathway." 447 U.S. at 305. The Court explained that "Plasmids are hereditary units physically separate from the chromosomes of the cell" that had the capability in certain combinations to degrade crude oil in oil spills. Id. at n.1. The Court noted, "This case does not involve the other 'conditions and requirements' of the patent laws, such as novelty and nonobviousness." Id. at n. 5 (citing 35 U.S.C. $\S \S 102-103$ ). In dissent, and speaking for Justices White, Marshall and Powell, Justice Brennan said, "The only question we need decide is whether Congress . . . intended that he [the inventor] be able to secure a monopoly on the living organism itself, no matter how produced or how used. Because I believe the Court has misread the applicable legislation, I dissent." 447 U.S. at 318

${ }^{90} 447$ U.S. at 305 ("We granted certiorari to determine whether a live, human-made micro-organism is patentable subject matter.").

${ }^{91} I d$. at 307 . Finding patentable subject matter, the Court did not state whether the bacteria was a manufacture or a composition of matter. Id. at 307-09.

${ }^{92} I d$. at 308 (quoting Am. Fruit Growers, 283 U.S. at 11.) See supra text accompanying notes 72-76.

${ }^{93}$ Id. at 308 (quoting Shell Dev. Co. v. Watson, 149 F.Supp. 279, 280 (D.C. 1957)).

${ }^{94} I d$. at 309 (The Court did not define "physical phenomena."). Parasidis, supra note 55, at 326, $332-33$ (citing Gottschalk v. Benson, 409 U.S. 63, 67 (1972) for the proposition that the product of nature doctrine "precludes eligibility for laws of nature, phenomenon, mental processes, and abstract ideas."). The Court in Gottschalk did refer to "natural phenomenon" as being unpatentable. See Diamond, 450 U.S. at 185 ("Excluded from such patent protection are laws of nature, natural phenomena, and abstract ideas."); see also Chakrabarty, 447 U.S. at 303 (used "physical phenomena" as the type of phenomena that constituted unpatentable subject matter.). This article uses
} 
reserved exclusively to none. ${ }^{95}$

The Court in Chakrabarty upheld the patent and concluded "the patentee has produced a new bacterium with markedly different characteristics from any found in nature and one having the potential for significant utility. His discovery is not nature's handiwork, but his own; accordingly it is patentable subject matter under $§ 101 .^{96}$ The Court explained the differences between the natural bacteria and the claimed invention in the second paragraph of the decision: "This human-made, genetically engineered bacterium is capable of breaking down multiple components of crude oil. Because of this property, which is possessed by no naturally occurring bacteria, Chakrabarty's invention is believed to have significant value for the treatment of oil spills." ${ }^{97}$ In other words, as in Funk Brothers, the Court again indicated that comparison of the function of the claimed invention to the natural function of the analogous composition was relevant. $^{98}$

It appears the Court in Chakrabarty referred to "phenomena" as the actions and natural functioning of the bacteria that had not been changed by humans to include plasmids. Before the insertion of the plasmids, the bacteria did not break down oil spills, but after the insertion the bacteria, the bacteria did break down oil spills. Humans changed the physical phenomena/functioning of the bacteria. ${ }^{99}$

Additionally, the Court held "that the relevant distinction was not between living and

"physical phenomenon" for the phenomena that are unpatentable, because that is the most current term used by the Supreme Court and because it expressly covers physical objects, and not simply abstract phenomena, consistent with prior Supreme Court cases. See supra notes 50-54, 72-76, 77-88 and accompanying text.

${ }^{95} 447$ U.S. at 309 (quoting Funk Bros, 333 U.S. at 130 (1948)).

${ }^{96} I d$. at 310 (emphasis added) (The Court did not discuss a standard for determining "markedly different.").

${ }^{97} I d$. at 305.

${ }^{98}$ Professors Conley and Makowski state that the principal distinction" between Funk and Chakrabarty appears to be that the Funk inventor did his work by mixing cells, whereas Chakrabarty had to introduce new genetic material within a cell.”. Conley \& Makowski, supra note 49, at 376.

${ }^{99} 447$ U.S. at 304. 
inanimate things, but between products of nature, whether living or not, and human-made inventions." ${ }^{100}$ Since the Court also held laws of nature, physical phenomena and abstract ideas were not patentable, the reference to "products of nature" being on the unpatentable side of the divide from human-made inventions indicates the Court considered "products of nature" to be a short-hand term for laws of nature, physical phenomena and abstract ideas. ${ }^{101}$

The Supreme Court followed its statement in Chakrabarty that "laws of nature, physical phenomena, and abstract ideas have been held not patentable" with citation to five earlier Supreme Court decisions: Parker v. Flook; Gottschalk v. Benson; Funk Brothers Seed Co. v. Kalo Inoculant Co.; O'Reilly v. Morse; and Le Roy v. Tatham. ${ }^{102}$ The phrase "physical phenomena" does not appear in Gottschalk, Funk Brothers, O'Reilly or Tatham, but it does appear in the dissenting opinion in Parker. Further, "natural phenomena" are discussed in the majority opinion, therefore it is appropriate to turn to Parker to confirm the meaning of unpatentable "phenomena." 103

\footnotetext{
${ }^{100} I d$.at 313. See J.E.M. Ag Supply v. Pioneer Hi-Bred Int'l, Inc., 534 U.S. 124, 130 (2001) (holding that the Plant Variety Protection Act and the Plant Patent Act of 1930 were not the exclusive means of obtaining a patent for human-developed plant breeds and confirming that the distinction the Court considered crucial under $\S 101$ was between "products of nature, whether living or not, and human-made inventions," (quoting Diamond v. Chakrabarty, 447 U.S. 303 (1980))). See also 534 U.S. at 127-128 ("Pedigree inbred corn plants are developed by crossing corn plants with desirable characteristics and then inbreeding the resulting plants for several generations until the resulting plant line is homogenous. Inbreds are often weak and have a low yield; their value lies primarily in their use for making hybrids. . . . . Hybrid seeds are produced by crossing two inbred corn plants and are especially valuable because they produce strong and vibrant hybrid plants with selected highly desirable characteristics."). See generally Plant Variety Protection Act,7 U.S.C. § 2321 (2006) and Plant Protection Act 35 U.S.C. §§ 161-164 (2006).

${ }^{101}$ Abstract ideas do not seem to fit nicely into a "product of nature" category. However, perhaps the Court thought of abstract ideas as "products of nature," to the extent the Court considers human beings - presumably the generator of such ideas - products of nature.

102447 U.S. at 309. Even though the results of Funk Bros. and Chakrabarty were different, Professors Conley and Makowski say the analysis in Chakrabarty shows that the Court believed Funk Bros. was "the definitive statement of the product of nature doctrine." Conley \& Makowski, supra note 49, at 376.

${ }^{103}$ Parker v. Flook, 437 U.S. 584 (1978) (deciding that a method for updating alarm limits during catalytic conversion did not constitute patentable subject matter. The Court agreed the method in question was a "process" in the ordinary sense of the word, but concluded that its prior holding foreclosed "a literal reading of $\S 101$ " as to the meaning of "process" for determining patentability.) Id. at 585, 588-89 (citing Gottschalk, 409 U.S. 63).
} 
The majority and dissent in Parker agreed on what in general did not constitute patentable subject matter. The majority wrote, "Phenomena of nature ...mental processes, and abstract intellectual concepts are not patentable, as they are the basic tools of scientific and technological work."104 The dissent in Parker started with a direct reference to "physical phenomena" and stated, "It is a commonplace that laws of nature, physical phenomena, and abstract ideas are not patentable subject matter," the exact three terms used in Chakrabarty and Bilski to describe the three categories of unpatentable subject matter. ${ }^{105}$ The examples of unpatentable subject matter mentioned by the dissent included both abstract concepts and physical matters: law of gravity, multiplication tables, magnetism, and "the fact that water at sea level boils at 100 degrees centigrade and freezes at zero." Presumably the dissent in Parker and there is no reason to conclude the majority disagreed - classified (1) the law of gravity as a law of nature, (2) multiplication tables as an abstract idea, and (3) magnetism and water boiling or freezing as physical phenomena.

\section{Lower court purification cases}

There were references in AMP2 to some of a series of lower federal courts in the twentieth century (largely decided before Funk Brothers and Chakrabarty), that involved the patentability of "purified" products -- material found in nature mixed together with other material from which the inventor had removed much or all of the other material or "impurities." ${ }^{106}$ Is purification the kind of human intervention into naturally occurring products that the Supreme

\footnotetext{
${ }^{104} I d$. at 589 (quoting Gottschalk, 409 U.S. at 67).

${ }^{105}$ Id. at 598.

${ }^{106}$ Patenting, supra note 9, at 14 ("The defendants [in AMP] argued . . . that the isolation and purification of a DNA molecule constitutes an alteration from the natural state, and as such, the DNA is no longer the natural product. Although the weight of the Supreme Court decisions forbids the patenting of naturally-derived products, proponents of patenting genes and other biomolecules base their arguments on lower court cases.").
} 
Court in Chakrabarty contemplated as the dividing between patentable and unpatentable subject matter? ${ }^{107}$ As some of these cases are mentioned in $A M P 2$, this article summarizes those cases here.

The courts rejecting patents on "purified" products considered more than comparing the chemical composition of the "purified" products with what was found in nature--the courts also considered the functioning use of the products. ${ }^{108}$ For instance, in General Electric Co. v. De Forest Radio Co., ${ }^{109}$ the court rejected product claims for substantially pure tungsten, since purified tungsten was ductile and could be shaped into wires for electric light bulbs, the same use as elemental tungsten, even though the form of tungsten that existed in nature is oxide of tungsten (WO 3), a highly brittle material. ${ }^{110}$ The court addressed the phrase "having ductility and high tensile strength," holding the phrase was just an accurate description of substantially pure tungsten. The court concluded claim 26 "claims as an invention a product of nature in the form of a chemical element for which a product claim as distinguished from a process claim cannot be validly awarded."111

Similarly, the courts upholding patents on purified products relied on not just the

\footnotetext{
${ }^{107}$ Patenting, supra note 9, at 13 ("what level of human intervention makes a product not natural, and court opinions diverge on when a product is significantly altered from its natural state to legitimize eligibility.").

${ }^{108}$ See Allen K. Yu, Why It Might Be Time To Eliminate Genomic Patents, Together With The Natural Extracts Doctrine Supporting Such Patents, 47 IDEA 659, 694 (2007) ("Under the natural extracts doctrine products extracted from nature constitute patentable subject matter as long as the extraction involves human intervention and the isolated product offers novel properties unavailable in the natural form.").

${ }^{109}$ Gen. Elec. Co. v. De Forest Radio Co., 28 F.2d 641 (3d Cir. 1928).

${ }^{110}$ Id. at 641-43; see also Gen. Elec. Co. v. De Forest Radio Co., 17 F.2d 90, 92 (D. Del. 1927), aff'd in part, rev'd in part 28 F.2d 641 (3d Cir. 1928) ("Tungsten is one of the elements. In nature it is found only in combination with other elements.... Throughout the century preceding the granting of the patent in issue, chemists and metallurgists asserted that tungsten hot or cold is nonductile.").

${ }^{111} I d$. at 643. Accord Parasidis, supra note 55, at 348 ("The General Electric case is particularly noteworthy because of the fact that the court held that the claims were invalid despite the fact that tungsten did not exist in nature in its pure form. In particular, the court reasoned that, because tungsten is a naturally occurring element, all of its properties are natural by definition.") and Conley \& Makowski, supra note 49, at 324 (-The most controversial aspect of the General Electric decision arises from the fact that the pure tungsten claimed by Coolidge had not been found in nature.").
} 
chemical composition of the products, but their uses. In Parke-Davis \& Co. v. H.K. Mulford Co., ${ }^{112}$ the courts upheld a patent for a product of extracts from the suprarenal glands of living animals, because the purification created a new product different in therapeutic effect from the natural material. $^{113}$ In Merck \& Co. v. Olin Mathieson Chemical Corp., the Fourth Circuit reversed the holding of the district court that the product claims for a Vitamin $\mathrm{B}(12)$ was unpatentable as a product of nature, ${ }^{114}$ again because of the additional therapeutic effects of the invention. ${ }^{115}$ Two cases involving patents for isolated DNA segments - Amgen, Inc. v. Chugai

\footnotetext{
${ }^{112} 189$ F. 95 (Cir. Ct., S.D.N.Y. 1911); aff'd in part and rev'd in part, 196 F. 496 (2d Cir. 1912). The first claim of the first of the two patents at issue read: "A substance possessing the herein-described physiological characteristics and reactions of the suprarenal glands in a stable and concentrated form, and practically free from inert and associated gland tissue." $196 \mathrm{~F}$. at 497.

${ }^{113}$ See, e.g., Jonah D. Jackson, Something Like The Sun: Why Even 'Isolated And Purified' Genes Are Still Products Of Nature, 89 TEX. L. REV. 1453, 1468-69 (2011) ("Finding that the claimed substance was different both in chemical composition . . . and in therapeutic effect . . . Judge Hand called these differences —at in degree, but in kind" and therefore patentable exceptions to the product of nature doctrine."). See generally University of Medical Center Endocrinology Health Guide, http://www.umm.edu/endocrin/adrengl.htm (last visited June 11, 2011) (Adrenal glands, "which are also called suprarenal glands, are small, triangular glands located on top of both kidneys ... The adrenal cortex, the outer portion of the adrenal gland, secretes hormones that have an effect on the body's metabolism, on chemicals in the blood, and on certain body characteristics.").

${ }^{114}$ Merck \& Co. v. Olin Mathieson Chem. Corp., 253 F.2d 156, 157-60 (4th Cir. 1958) (Claim 1 of the patent read: "A vitamin B(12)-active composition comprising recovered elaboration products of the fermentation of a vitamin $\mathrm{B}(12)$-activity producing strain of Fungi selected from the class consisting of Schizomycetes, Torula, and Eremothecium, the L.L.D. activity of said composition being at least 440 L.L.D. units per milligram and less than 11 million L.L.D. units per milligram." The Fourth Circuit said, "The claims of this patent do not reach pure, crystalline vitamin $\mathrm{B}(12)$, for they are restricted to compositions having a maximum LLD activity which is less than that of the pure substance. The claims do not cover vitamin $\mathrm{B}(12)$ compositions derived from liver or any source other than the specified fermentates. Nor do the claims extend to compositions of such low activity as to be of no commercial or therapeutic value. They do cover B(12)-active compositions derived from the specified fermentates, which, beyond question, are of very great therapeutic and commercial importance.").

${ }^{115} I d$. at 162-163 (the Fourth Circuit relied on the functioning of the invention, not simply its chemical composition, in concluding, "[t]he new product ... had such advantageous characteristics as to replace the liver products." The Fourth Circuit also said "[a] product of nature which is not a new and useful machine, manufacture, or composition of matter' is not patentable, for it is not within the statutory definition of those things which may be patented. Even though it be a new and useful composition of matter it still may be unpatentable if the subject matter as a whole was obvious within the meaning of 35 U.S.C. $§ 103$, or if other conditions of patentability are not satisfied. In dealing with such considerations, unpatentable products have been frequently characterized as products of nature." (citing Funk Bros. Seed Co. v. Kalo Inoculant Co., 333 U.S. 127 (1948)); see also Jackson supra note 133 at 1469 ("The effects of the purified $\mathrm{B}_{12}$ were different than those of any previously known compound-- a difference in kind, not merely in degree of purity."). In analyzing Merck, Professors Conley and Makowski said that "one wonders whether it is being suggested that great utility, standing alone, can trump product of nature status." Conley \& Makowski, supra note 49, at 328-329. In any case, the effects of the product are relevant to patentability.
} 
Pharmaceutical Co., Ltd., ${ }^{116}$ and Intervet Inc. v Merial Ltd. ${ }^{117}$ - but neither Amgen nor Intervet included a holding on whether isolated DNA segments could constitute patentable subject matter. Intervet is particularly interesting due to the separate opinion of Judge Dyk, concurring in part and dissenting in part "to make clear that in construing the claims, we are not deciding that the claims as construed are limited to patentable subject matter." ${ }^{118}$ Patentable subject matter was not at issue or ruled upon. ${ }^{119}$

Judge Dyk observed that although the Federal Circuit had upheld several gene patents, neither the Supreme Court nor the Federal Circuit had "directly decided the issue of the patentability of isolated DNA molecules."120 The majority did not disagree with that statement. Judge Dyk made three comments summarizing his reasoning that at least one claim of the patent

\footnotetext{
${ }^{116}$ Amgen, Inc. v. Chugai Pharmaceutical Co., Ltd., CIV. A. No. 87-2617-Y, 1989 WL 169006, at *32 (D. Mass. Dec. 11, 1989), aff'd in part, vacated in part, 927 F.2d 1200 (Fed. Cir. 1991) (noting that "claim 2 of the patent is the 'purified and isolated' DNA sequence encoding human erythropoietin") $I d$. at *32. Defendants challenged the validity of the patent, but did not claim the patent constituted unpatentable subject matter, and the District Court upheld the validity of most of the patent claims. Defendant challenged the validity of the patent on grounds of anticipation under $\S 102$ by a Dr. Fritsch, obviousness under $\S 103$, failure to comply with the best mode requirement of $\S 112$ and failure to comply with the enablement requirement of $\S 112$. Id. at *86 (summary of the court's conclusions). In dicta, the District Court made the following statement: "The invention claimed in the '08 patent is not as plaintiff argues the DNA sequence encoding human EPO since that is a nonpatentable natural phenomenon 'free to all men and reserved exclusively to none."' Id. at*32 (quoting Funk Bros., 333 U.S. at 130). On appeal, the Federal Circuit in Amgen reversed the District Court and held that certain of the patent claims had not been enabled by the patent specification. The Federal Circuit added, "we do not intend to imply that generic claims to genetic sequences cannot be valid where they are of a scope appropriate to the invention disclosed by an applicant." However, there was no holding by the Federal Circuit that isolated DNA segments constituted patentable subject matter. 927 F.2d at 1212-1214(holding that the patent specification had not enabled claims 7, 8, 23-27 and 29 of the '008 patent.). Janice M. Mueller, Patent Law 103 (3rd ed., Aspen Publishers 2009) (Under the enablement provision in $\S 112$, "an inventor must disclose [in the patent application] both 'how to make' the invention as well as 'how to use' it.").

${ }^{117}$ Intervet, Inc. v. Merial, Ltd., 617 F.3d 1282, 1292-96 (Fed. Cir. 2010) (Dky, J., concurring in part and dissenting in part).

${ }^{118} I d$. at 1292 (Dyk, J., concurring); Id. at 1284, 1286 (discussing Intervet's filing of a declaratory judgment action asking the court to declare that Intervet was not infringing the patens of defendant Merial. One of the product claims was for "[a]n isolated DNA molecule comprising a nucleotide sequence encoding an epitope which is specific to PCV-2 and not specific to PCV-1." The District Court granted summary judgment of non-infringement. Invervet, Inc., v. Merial, Ltd., 643 F. Supp. 2 d. 97 (D.D.C. 2009) vacated sub. nom., Intervet, Inc. v. Merial, Ltd., 617 F.3d 1282 (Fed. Cir. 2010). The Federal Circuit reversed the District Court's claim construction and remanded for a determination if the accused product infringed the claims as constructed. Intervet, 617 F.3d at 1292.

${ }^{118}$ Intervet, 617 F.2d at 1287 , n. 4.

${ }^{119}$ Intervet, 617 F.2d at 1287 , n. 4

${ }^{120} I d$. at 1293 (Dyk, J., concurring).
} 
raised "substantial issues of patentable subject matter under 35 U.S.C. $§ 101: " 121$

- $\quad$ [A]llowing the patenting of naturally occurring substances [would] preempt the use by others of substances that should be freely available to the public." 122

- $\quad$ [I]n order for a product of nature to satisfy section 101 , it must be qualitatively different from the product occurring in nature, with 'markedly different characteristics from any found in nature.' It is far from clear that an 'isolated' DNA sequence is qualitatively different from the product occurring in nature such that it would pass the test laid out in Funk Brothers and Chakrabarty." 123

- $\quad$ The mere fact that such a DNA molecule does not occur in isolated form in nature does not, by itself, answer the question [of patentable subject matter]. It would be difficult to argue, for instance, that one could patent the leaves of a plant merely because the leaves do not occur in nature in their isolated form." 124

Explaining why it was not deciding the issue of patentable subject matter, the majority said, "[w]e do not address the issues of validity and non-patentable subject matter discussed by the dissent because these issues were not addressed by the district court or raised on appeal." 125

\section{Summary of twentieth century cases}

In determining whether a claimed invention contains patentable subject matter, the Supreme Court considers not only the composition, but the characteristics and functioning of both the invention and the related natural product. In American Fruit Growers the Supreme Court concluded that the fact that borax, when inserted into the orange, increased the life of the orange, was not sufficient for patentability, because the orange remained "fit only for the same

\footnotetext{
${ }^{121} I d$. at 1292-93 (Dyk, J., concurring) ("The question is whether the isolated DNA molecule, separate from any applications [i.e., uses] associated with the isolated nucleotide sequence (for example, the production of a vaccine) is patentable subject matter.").

${ }^{122} I d$. at 1294 (Dyk, J, concurring).

${ }^{123} I d$. at 1294-1295 (Dyk, J., concurring).

${ }^{124}$ Intervet, 617 F.3d at 1295 (Dyk, J., concurring).

${ }^{125} I d$. at 1287, n. 4.
} 
beneficial uses as theretofore." ${ }^{126}$ In Funk Bros., the Court concluded that since there had been no change in the "state of inhibition or of non-inhibition in the bacteria," the bacteria were "manifestations of laws of nature, free to all men and reserved exclusively to none." ${ }^{127}$ In Chakrabarty, the Court held that the bacteria constituted patentable subject matter because "the patentee has produced a new bacterium with markedly different characteristics from any found in nature and one having the potential for significant utility;" 128 specifically, "[t]his human-made, genetically engineered bacterium is capable of breaking down multiple components of crude oil." 129

Put another way, the Supreme Court considers whether the claimed invention has changed the work of nature--the natural or physical phenomena. If not, the invention does not claim patentable subject matter. Professor Parasidis wrote, "Claims over purified or isolated stem cells are ineligible where ... natural properties of the cells are the proximate cause of any distinction between the subject matter of the isolated or purified stem cell from the non-isolated or non-purified cells." ${ }^{130}$ Specifically discussing Funk Bros., Professor Kane wrote 'No human intervention accounted for the properties exhibited by the bacteria, and the Court separated discovery from invention." ${ }^{131}$ Also discussing Funk Bros., Professors Conley and Makowski wrote that the "fairer characterization of the holding is that Bond failed because his real and only discovery was the product of nature, which he applied in the most obvious way possible: exactly as he found it. In other words, his patent was denied because his purported application" was not

\footnotetext{
${ }^{126} 283$ U.S. at $11-12$.

${ }^{127} 333$ U.S. at 130.

${ }^{128} 447$ U.S. at 310.

${ }^{129}$ Id. at 305.

${ }^{130}$ Paradisis, supra note 55, at 402-403 (emphasis added) (discussing purified and isolated stem cells instead of isolated and purified DNA segments, Professor Paradisis analyzed the same cases as set forth in this section, and her conclusion also seems applicable to isolated and purified DNA segments).

${ }^{131}$ Splitting, supra note 33, at 734 (emphasis added).
} 
materially distinguishable from the work of nature." ${ }^{132}$ As discussed next, however, the Majority Opinion disregards the work of nature, the natural properties of the DNA segments.

\section{ASSOCIATION FOR MOLECULAR PATHOLOGY vs. U.S. PATENT AND TRADEMARK OFFICE ${ }^{133}$ and MYRIAD GENETICS, INC.}

The Majority Opinion and Concurring Opinion together focus on three issues: (a) comparing the chemical compositions of the isolated DNA segments with the entire DNA strands and chromosomes rather than with the individual gene; (b) the utility to humans of some of the short isolated DNA segments; and (c) the fact the USPTO had been granting "gene patents" for years. $^{134}$ This article examines these issues, but first discusses the representative patent claims in the case.

\section{A. The Representative Patents}

$A M P 2$ involves both process and product patents, and there are three representative product claims. The first claim for the $=282$ patent is: ${ }^{135}$ "An isolated DNA coding for a BRCA1 polypeptide, said polypeptide having the amino acid sequence set forth in SEQ ID NO:2."136 The second claim for the 282 patent is the following dependent claim: "The isolated DNA of claim 1, wherein said DNA has the nucleotide sequence set forth in SEQW ID NO;1. ${ }^{137}$ The $5^{\text {th }}$ claim for the 282 patent is:"An isolated DNA having at least 15 nucleotides of the DNA of

\footnotetext{
${ }^{132}$ Rethinking1, supra note 49, at 334 (Emphasis added). For the view of Funk Bros. that Professors Conley and Makowski did not agree with, see supra note 88.

${ }^{133}$ The District Court granted the USPTO's motion for judgment on the constitutional issue raised against the USPTO. See supra note 9.

${ }^{134}$ Judge Moore also referred to prior litigation involving DNA (which did not involve any holding that isolated DNA segments constituted patentable subject matter), settled expectations, extensive property rights, and inaction of Congress, all discussed in part B below.

${ }^{135}$ The Majority Opinion identified the other patents assigned to Myriad in AMP2, 653 F.3d at 1334.

${ }^{136}$ U.S. Patent No. 5,747,282, at 153 (filed June 7, 1995).

${ }^{137} I d$.
} 
claim 1."138 These claims give Myriad the right to sue anyone that uses the segments identified, regardless of how the other party made the segments. ${ }^{139}$

The 282 Patent defines an "isolated . . . nucleic acid" as "one which is substantially separated from other cellular components which naturally accompany a native human sequence or protein ...." ${ }^{140}$ The $\_282$ Patent says a "polynucleotide is said to 'encode' a polypeptide if, in its native state or when manipulated by methods well known to those skilled in the art, it can be transcribed and/or translated to produce the mRNA for the polypeptide or a fragment thereof." 141

The size of the BRCA1 gene varies significantly depending on whether it is in native or isolated form. The BRCA1 gene in its native state contains around eighty million nucleotides. The isolated BRCA1 gene with both exons and introns consists of approximately 80,000 nucleotides. Without introns, BRCA1 has around 5,500 nucleotides. ${ }^{142}$

This article only addresses the decision in $A M P 2$ holding that claim 1 of the '282 patent constitutes patentable subject matter. Claim 2 involves $\mathrm{cDNA}^{143}$ and the facts specific to cDNA, and the three judges in AMP2 agreed that this claim involved patentable subject matter. ${ }^{144}$ Claim 5 can include much shorter segments of DNA than claims 1 and $2,{ }^{145}$ and the argument that claim

\footnotetext{
${ }^{138} I d$. The Majority Opinion refers to these three claims as "representative composition claims" in $A M P 2,653 \mathrm{~F} .3 \mathrm{~d}$ at 1334.

${ }^{139}$ For comparisons of product patents, process patents and product by process patents, see Robert P. Merges \& Richard R. Nelson, On The Complex Economics Of Patent Scope, 90 ColuM. L. REV. 839, 851-852 ( 1990); see Laurie L. Hill, The Race to Patent the Genome: Free Riders, Hold Ups, and the Future of Medical Breakthroughs, 11 TEX. InTELl. Prop. L. J. 221, 233-34 (2003);,Nese, supra note 5, at 148-49. For further discussion of "product by process" claims, see notes 191-194 below and accompanying text.

${ }^{140}$ See 282, at 19 .

${ }^{141} I d$.

${ }^{142}$ AMP2, 653 F.3d at 1351-52 .

${ }^{143}$ See Id. at 1364.

${ }^{144}$ The failure of this article to address whether claim 2 or claim 5 recite patentable subject matter does not indicate agreement or disagreement with the result in $A M P 2$ on claim 2 or on claim 5.

${ }^{145}$ See, e.g., $A M P 2,653$ F.3d at 1364.
} 
1 does not constitute patentable subject matter presents the issue of patentable subject matter more clearly than does claim $5 .^{146}$

\section{B. Is Isolated DNA Markedly Different than the Native DNA?}

\section{Looking solely at chemical composition}

In $A M P 1$ the District Court referred to genes as "basic units of heredity found in all living organisms," ${ }^{147}$ but Judges Lourie and Moore both looked past these basic units. Judge Lourie said, Native DNA exists in the body as one of forty-six large, contiguous DNA molecules. Each DNA molecule is itself an integral part of a larger structural complex, a chromosome. In each chromosome, the DNA molecule is packaged around histone proteins into a structure called chromatin, which in turn is packaged into the chromosomal structure."148 Judge Moore concentrated on the individual chemical bonds remaining after isolation of one gene from other genes, saying Instead of being connected to many thousands of additional nucleotides at the $3^{\text {c }}$ and $5^{6}$ ends of the sequence in question, as is the case in the chromosome, the isolated DNA molecules terminate in, for example, a hydroxyl and a phosphate group, respectively."149 The paths of Judges Lourie and Moore diverged on the relevance of the difference in functioning between the shorter and longer isolated DNA segments.

\footnotetext{
${ }^{146}$ The comparison of short and long DNA segments is discussed as part of this article's discussion of claim 1 . See text accompanying notes 159-166.

${ }^{147} A M P 1,702$ F. Supp. 2 d at 194.

${ }^{148} A M P 2,653$ F.3d at 1351. (Judge Moore also referred to the connection of a specified gene to the other parts of the chromosome as significant and added, There are other differences between an isolated DNA sequence and that same DNA sequence as part of the chromosome.") Id. at 1363.

${ }^{149} I d$. at 1363 . (It is not clear why Judge and Moore did not go further in his comparison, since chromosomes are integral parts of a larger structural complex, cells. Would Judge Moore have concluded that a chromosome removed from the cell constituted patentable subject matter?).
} 


\section{Judge Lourie rejected considering uses/functioning of isolated DNA in determining whether the "invention" is markedly different than native DNA}

Although Judge Lourie referred to Myriad‘s argument that -isolated DNAs, unlike native DNAs, can be used as primers and probes for diagnosing cancer," ${ }^{, 150}$ he did not rely on such uses to justify his conclusion the isolated DNA segments constituted patentable subject matter. Instead, he concluded that it is the distinctive nature of DNA molecules as isolated compositions of matter that determines their patent eligibility rather than their physiological use or benefit." ${ }^{, 151}$ Judge Lourie dismissed the importance of the identical nucleotide sequences by indicating the court must consider the differences of the chemical compositions rather than the similarity of the genetic code--or the "information content" of the DNA (as Judge Lourie labeled the genetic code). ${ }^{152}$

Judge Lourie also rejected any consideration of the fact that both native DNA and the isolated DNA segments coded for the same polypeptides regardless of any difference in chemical composition. ${ }^{153}$ Specifically, he said, Uses of chemical substances may be relevant to the nonobviousness of these substances or to method claims embodying those uses, but the patent eligibility of an isolated DNA is not negated because it has similar informational properties to a different, more complex natural material." ${ }^{154}$ Judge Lourie also said, $\left.₫ w\right]$ e recognize that

\footnotetext{
${ }^{150} I d$. at 1349 .

${ }^{151} I d$. at 1353.

${ }^{152} I d$. ("Plaintiffs argue that because the claimed isolated DNAs retain the same nucleotide sequence as native DNAs, they do not have any 'markedly different' characteristics. This approach, however, looks not at whether isolated DNAs are markedly different-have a distinctive characteristic - from naturally occurring DNAs, as the Supreme Court has directed, but at one similarity: the information content contained in isolated and native DNAs' nucleotide sequence.").

${ }^{153}$ Claim 1 of patent ' 282 is for "An isolated DNA coding for a BRCA1 polypeptide, said polypeptide having the amino acid sequence set forth in SEQ ID NO:2." See supra note 136. Judge Moore noted in AMP2 at 1366, "Some of the claims at issue.... are genus claims, drafted broadly enough to include both short fragments as well as the entire isolated gene sequence.".

${ }^{154} A M P 2,653$ F.3d at 1353.
} 
biologists may think of molecules in terms of their uses, but genes are in fact materials having a chemical nature and, as such are best described in patents by their structures rather than their functions. ${ }^{155}$

Removing consideration of function from patentable subject matter and relegating function to the separate statutory question of non-obviousness under $\S 103$ or description under $\S 112$ is inconsistent with Chakrabarty and Flook Bros. ${ }^{156}$ In Chakbrabarty the only issue was whether the bacteria constituted patentable subject matter. In Chakrabarty, the Supreme Court in contrast to Judge Lourie - considered the uses of the bacteria in determining patentable subject matter, observing: "This human-made, genetically engineered bacterium is capable of breaking down multiple components of crude oil." ${ }^{157}$ In Funk Bros., the Supreme Court invalidated the patent because there had been -no enlargement of the range of their [the bacteria 's] utility" and the bacteria perform in their natural way." 158 In both cases the Supreme Court considered functioning of the product, in one finding patentable subject matter in one and the other not

\footnotetext{
${ }^{155} I d$. (emphasis added). See Splitting, supra note 33, at 708 ("Genes are identified as the discrete units of DNA sequence that encode individual proteins and that collectively underlie the biochemical design of any organism."). HORTON, infra note 299 at 816 (defining the "genetic code" as "The correspondence between a particular nucleotide codon and the amino acid it specifies. The standard genetic code of 64 codons is used by almost all organisms. The genetic code is used to translate the sequence of nucleotides in mRNA into protein."); See also notes 308-14.

${ }^{156} \S 103$ (a) provides, " A patent may not be obtained though the invention is not identically disclosed or described as set forth in section 102 of this title, if the differences between the subject matter sought to be patented and the prior art are such that the subject matter as a whole would have been obvious at the time the invention was made to a person having ordinary skill in the art to which said subject matter pertains. Patentability shall not be negatived by the manner in which the invention was made." Paragraph 2 of $\S 112$ provides, "The specification shall conclude with one or more claims particularly pointing out and distinctly claiming the subject matter which the applicant regards as his invention." However, judges on the Federal Circuit in addition to Judge Lourie, have also written opinions recently appearing to diminish the exceptions to patentable subject matter under $\S 101$. For instance, in Classen Immunothererapies, Inc. v. Biogen Idec, 2011 WL 3835409, the majority opinion, written by Judge Newman, referred to $\S 101$ as a "course eligibility filter" and added the "patentability of subject matter that is facially within the classes set forth in $\S 101$ is most reliably resolved in accordance with the conditions of $\S \S 102$, 103 and 112." Id. at *8 Also in Classen, Chief Judge Rader gave the following additional view, in which Judge Newman joined: "This court should decline to accept invitations to restrict subject matter eligibility." Id. at * 15 . Attempting to diminish the trilogy of exceptions appears inconsistent with the Supreme Courts affirmation in Bilski laws of nature, physical phenomena and abstract ideas have "defined the reach of the statute [§101] as a matter of statutory stare decisis going back 150 years." Bilski, 130 S. Ct. at 3225.

${ }^{157} 447$ U.S. at 304.

${ }^{158} 333$ U.S. at 131.
}

PGH. J. TECH. L. \& POL'Y, Vol. 12, No. 3, Fall 2011 
finding patentable subject matter in the other.

\section{Judge Moore did not identify any different use/functioning of the isolated segments of claim 1 from native DNA}

Judge Moore, on the other hand, did not disregard Chakrabarty or Funk Bros. and did consider the uses/functioning of the isolated DNA segments. Judge Moore began by looking at claim 5 of the '282 patent: "An isolated DNA having at least 15 nucleotides of the DNA of claim 1."159 With respect to those segments, Judge Moore found, "The shorter isolated DNA sequences ... can be used as primers in a diagnostic screening process to detect gene mutations. These smaller isolated DNA sequences ... can also be used as the basis for probes. Naturally occurring DNA cannot be used to accomplish these same goals. ${ }^{160}$ As a result, Judge Moore concluded that the shorter DNA segments of claim 5 had a "different and beneficial utility," and the "small segments are patentable subject matter."161

Judge Moore took a different position with the longer segments, such as the segments of claim 1, which could be as long as 5,000 nucleotides, even with the introns removed. ${ }^{162}$ Relying on Funk Bros., she said, "Unlike the shorter strands of isolated DNA, the chemical and structural differences in the isolated gene do not clearly lead to an _enlargement of the range of ... utility as compared to nature." ${ }^{163}$ She made the following two observations:

- $\quad$ "the full length gene is too large to be used as a probe." 164

\footnotetext{
${ }^{159} A M P 2,653$ F.3d at 1334 (citing U.S. Patent No.5,747,282, at [153-54] (filed May 5, 1998)). The Majority Opinion refers to these three claims as representative composition claims". Id. at 1365.

${ }^{160} I d$. at 1365.

${ }^{161} I d$.

${ }^{162} I d$. at 1366.

${ }^{163} I d$. Similarly, Judge Bryson stated, "What is claimed in the BRCA genes is the genetic coding material, and that material is the same, structurally and functionally, in both the native gene and the isolated form of the gene." Id. at 1378 .

${ }^{164} I d$. at 1366.
}

PGH. J. TeCh. L. \& POL'Y, Vol. 12, No. 3, Fall 2011 
- Likewise, an entire isolated gene appears unsuitable for use as a primer in genetic screening for mutations in that same gene." 165

She concluded the paragraph by repeating that "the chemical and structural differences in an isolated DNA sequence which includes most or all of a gene do not clearly lead to significant new utility as compared to nature." 166

Judge Moore then stated, "If I were deciding this case on a blank canvas, I might conclude that an isolated DNA sequence that includes most or all of a gene is not patentable subject matter." 167 However, she deferred to past events (discussed in part IIIC below) and concurred in the judgment of Judge Lourie with respect to isolated DNA sequences. ${ }^{168}$

\section{Judge Bryson's dissent that isolated DNA segments are not markedly different}

Judge Bryson rejected the foundation of Judge Lourie's position that removing the gene/DNA segment from the other genes/DNA segments and histones was significant for the issue of patentable subject matter. He said, The only material change made to those genes from their natural state is the change that is necessarily incidental to the extraction of the genes from

\footnotetext{
${ }^{165} A M P 2,653$ F,3d at 1366. Similarly, Judge Bryson said, "as Judge Moore's concurring opinion explains, Myriad has failed to credibly identify new uses for the isolated BRCA genes as probes or primers." Id. at 1378.

${ }^{166} I d$. at 1366. Judge Moore added, "[w] hether an isolated gene is patentable subject matter depends on how much weight is allocated to the different structure as compared to the similarity of the function to nature." Id. Yet his next sentence was, "If I were deciding this case on a blank canvas, I might conclude that an isolated DNA sequence that includes most or all of a gene is not patentable subject matter". Id. So it appears that whatever weight he assigned favored the conclusion that the isolated gene was not patentable. More importantly, in American Fruit Growers, Funk Bros. and Chakrabarty, the Supreme Court focused on whether the claimed inventor added anything to the naturally occurring object (yes in American Fruit Growers and Chakrabarty and no in Funk Bros.), and if human beings had added something, did that addition change the functioning of the object (no in American Fruit Growers and yes in Chakrabarty). In other words, the conclusion is that a change in composition was necessary, but the end question was whether there was a change in functioning, not a weighing of the additions to the composition vs. any change in function. This conclusion fits with the statement in Chakrabarty that there was a change in composition and increased utility, or at least a potential for significantly increased utility. See infra text accompanying note 177. ${ }^{167} A M P 2,653$ F.ed at 1366.

${ }^{168} I d$. at 1358. Although this article focuses on claim 1, Judge Moore concurred with Judge Lourie's opinion with respect to all the method claims and the claims to isolated cDNA claims and concurred with the judgment with respect to the "remaining sequences." $I d$.
} 
the environment in which they are found in nature." ${ }^{69}$ He added, $\left.\mathrm{fT}\right]$ he process of extracting minerals, or taking cuttings from wild plants, like the process of isolating genetic material, can result in some physical or chemical changes to the natural substance," but to not make extracted minerals or plant cuttings patentable, and they should not have that effect for isolated genes." 170

Judge Bryson also argued that the isolated genes identified in claim 1 in fact do exist in nature, albeit for a short time. He said, Đuring the transcription phase of protein synthesis, the BRCA genes are separated from chromosomal proteins. The transcription process then proceeds from a starting point called the promoter to a stopping point often called the terminator." 171

More importantly, Judge Bryson saw the forest - each of these isolated DNA segments eodes for the same protein as the naturally occurring BRCA1 gene."172 Judge Bryson focused more on the functioning of the isolated genes, saying -each gene must function in the same manner in the laboratory as it does in the human body. Indeed, that identity of function in the isolated gene is the key to its value."

Judge Bryson also gave the example of lithium, which does not appear naturally because

\footnotetext{
${ }^{169} I d$. at 1375 .

${ }^{170} I d$. In response to this leaf example, Judge Moore said, "With respect, no one could contemplate that snapping a leaf from a tree would be worthy of a patent, whereas isolating genes to provide useful diagnostic tools and medicines is surely what the patent laws are intended to encourage and protect. Snapping a leaf from a tree is a physical separation, not one creating a new chemical entity." Id. at 1354. This response is difficult to understand, since Judge Moore also said the longer isolated DNA samples did not present any significant additional utility (see note 163 above). Moreover, Judge Moore cited no evidence about what happened when someone snaps a leaf from a tree, but presumably there were some living, chemical connections between the leaf and the tree before the leaf was snapped, and presumably those connections changed with the snapping. Since Judge Moore considered precisely the changes in covalent bonds when a DNA segment is isolated ("a covalent bond is the defining boundary between one molecule and another," Id. at 1352), it seems inconsistent to reject the possibility - without considering the facts/evidence - of similar changes in bonds between molecules when a leaf is snapped from a tree.

${ }^{171}$ AMP2, 653 F.3d at 1376-77. For instance, during transcription, the DNA segments are separated from the proteins in the chromosomes and from other genes in the DNA. See discussion of transcription in Appendix at text accompanying notes 314-320 below.

${ }^{172} \mathrm{Id}$. at 1376 .

${ }^{173} \mathrm{Id}$. at 1378 .
} 
it reacts with air and water to form chemical compounds ionically bound to other elements. ${ }^{174}$

He continued that when lithium was isolated as an element, it had many industrial applications.

He said that the majority acknowledges that elemental lithium (like other elements) would not

be patentable subject matter because it _is the same element whether it is in the earth or isolated. " 175 In other words, Judge Bryson was arguing that elemental lithium would not be patentable if it were removed from its natural form and the chemical bonds changed, so isolated DNA is not patentable when the analogous process from the nucleotides are removed from its form inside our bodies. ${ }^{176}$

\section{Summary}

\section{Markedly different}

Judge Lourie: isolated DNA markedly different

Judge Moore: isolated DNA not markedly different

Judge Bryson: isolated DNA not markedly different

To determine whether or not material is an unpatentable "product of nature" or a -manmade" composition, a court must consider not simply the chemical composition of that matter but also its characteristics and natural functioning. In Chakrabarty, after all, the Court upheld

\footnotetext{
${ }^{174} I d$. at 1376.

${ }^{175} \mathrm{Id}$.

${ }^{176}$ Judge Lourie responded to Judge Bryson's lithium example as follows: "The dissent indicates that we 'acknowledge[ ] that elemental lithium (like other elements) would not be patentable subject matter because it is the same element whether it is in earth or isolated.' Again, these facts are not before us, so we do not attempt to evaluate the patentability of one form of lithium over another. Suffice it to say, however, that if lithium is found in the earth as other than elemental lithium, such as 'in molecular form' 'because it reacts with air and water,' it is not the same material as elemental lithium." AMP2, 653 F.3d at 1354. Yet Judge Moore also said in the paragraph immediately preceding his response to the Dissent, "Elemental lithium is the same element whether it is in the earth or isolated...". Id. This certainly suggests that Judge Lourie would consider lithium separated from its natural state on earth as not patentable. However, Judge Lourie avoids answering Judge Bryson's argument that elemental lithium isolated from nature would not be patentable, so by analogy DNA segments isolated from nature should also not constitute patentable subject matter. Although whether the element lithium would be patentable subject matter was not at issue in $A M P 2$, consideration of the consequences of a decision on a case in other areas is reasonable, at least in part to confirm whether or not the decision in the case at hand makes sense (the decision in General Electric, discussed infra at notes 108-111 above, would support the conclusion that isolated element lithium would not be patentable subject matter).
} 
the patent and explained, "the patentee has produced a new bacterium with markedly different characteristics from any found in nature and one having the potential for significant utility.",177 Judge Lourie acknowledged this consideration of function in Chakrabarty when he said, The bacteria, as a result [of the man-made genetic engineering] could break down multiple components of crude oil, a trait possessed by no single naturally occurring bacterium and of significant use in more efficiently treating oil spills."

In Funk Bros. the Supreme Court also considered function of the aggregation of bacteria, explaining that there had been mo enlargement of the range of their [the bacteria 's] utility" and that the bacteria perform in their natural way." ${ }^{179}$ In AMP2 Judge Moore said, Even though an invention did not previously exist in nature in exactly the claimed state, however, does not automatically mean it is patentable subject matter," citing Funk Bros. ${ }^{180}$ In other words, Judge Moore agreed that the fact native DNA did not exist in nature in exactly the same form as isolated DNA did not mean isolated DNA was patentable -- the Supreme Court considers the functioning of the bacteria. ${ }^{181}$

Under Chakrabarty and Funk Bros., it was error for Judge Lourie to reject consideration of the function and uses of the isolated DNA segments in determining whether or not the product

\footnotetext{
${ }^{177} 447$ U.S. at 310 (emphasis added). Not surprisingly, "characteristic" has more than one dictionary definition. Webster's Third New International Dictionary of the English Language Unabridged (2002) includes the following two definitions: "a trait, quality, or property or a group of them distinguishing an individual, group or type"; and "any of the variables pertaining to the normal performance of a device (as the grid voltage, plate current, or tube resistance of a vacuum tube or the voltage and watt rating of a lamp)." It is not important to determine whether in Chakrabarty the Court was referring to only static characteristics or performance characteristics, because clearly the Court referred to "utility" and considered the functioning of the native bacteria and the human-altered bacteria.

${ }^{178}$ AMP2, 653 F.3d at 1350 (citing Chakrabarty at 47 U.S. at 305, n.2.); See also AMP1, 702 F. Supp. $2 \mathrm{~d}$ at 223.

${ }^{179} 333$ U.S. at 131.

${ }^{180} A M P 2,653$ F.3d at 1359.

${ }^{181}$ Judge Moore concluded, "Even though an invention did not previously exist in nature inexactly the claimed state, however, does not automatically mean it is patentable subject matter." Id. To support this conclusion, Judge Moore quoted Funk Bros., saying, - - Ech species has the same effect it always had. The bacteria perform in their natural way." Id.
} 
claims constituted patentable subject matter. He removed consideration of function and use from consideration of patentable subject matter under $\S 101$ and relegated consideration of the function and use of the DNA segments to $\S 103$ (obviousness) and $\S 112$ (description and enablement). If a court does not consider the function of a product in determining patentable subject matter, the court cannot determine if the invention is an unpatentable physical phenomenon or law of nature and eviscerates $\S 101 .^{182}$

On the other hand, Judge Bryson appropriately concluded that the isolated DNA segments of claim 1 were not markedly different from the native DNA, ${ }^{183}$ and Judge Moore appropriately concluded that there was no evidence the isolated DNA segments of claim 1 had different uses from the native DNA. ${ }^{184}$ This would logically lead to the conclusion by both Judges Bryson and Moore that at least claim 1 did not constitute patentable subject matter. ${ }^{185}$

\footnotetext{
${ }^{182} \mathrm{Cf}$. Conley \& Mackowski, supra note 49, at 303 ("some courts and authorities have taken the position that patentable subject matter status is not an independent requirement, but merely a label to be applied when a claimed invention is found to be new and useful ....We shall argue, however, that this view has been squarely repudiated by the Supreme Court, most importantly in Diamond v. Chakrabarty.").

${ }^{183}$ "The structural differences between the claimed isolated" genes and the corresponding portion of the native genes are irrelevant to the claim limitations, to the functioning of the genes, and to their utility in their isolated form. The use to which the genetic material can be put, i.e., determining its sequence in a clinical setting, is not a new use; it is only a consequence of possession. In order to sequence an isolated gene, each gene must function in the same manner in the laboratory as it does in the human body. Indeed, that identity of function in the isolated gene is the key to its value. Moreover, as Judge Moore's concurring opinion explains, Myriad has failed to credibly identify new uses for the isolated BRCA genes as probes or primers. The naturally occurring genetic material thus has not been altered in a way that would matter under the standard set forth in Chakrabarty." AMP2, 653 F.3d at 1378.

${ }^{184}$ As mentioned infra at Part III.B.3, Judge Moore said "the full length gene is too large to be used as a probe .... Likewise, an entire isolated gene appears unsuitable for use as a primer in genetic screening for mutations in that same gene .... As such, the chemical and structural differences in an isolated DNA sequence which includes most or all of a gene do not clearly lead to significant new utility as compared to nature. "Id. at *31. See also John M. Conley, Gene Patents And The Product of Nature Doctrine, 84 CHI.-Kent L. Rev. 109, 120 (2009) ("the breast cancer or tumor suppressor gene patents claim DNA sequences that are defined by the fact that they do exactly the same coding work as the versions that occur in the body.").

${ }^{185}$ In $A M P 1$ and $A M P 2$, there did not appear to be any dispute of facts among the decisions, except on cDNA, and this article does not address claim 5, involving cDNA. The Federal Circuit reversed the District Court's grant of summary judgment on the product claims, but did not expressly direct the District Court on remand either (1) to grant summary judgment for Myriad on the product claims or (2) to set the case for trial on the product claims. See generally Patricia M. Wald, Summary Judgment At Sixty, 76 TEX. L. REV. 1897 (1998); Martin H. Redish, Summary Judgment And The Vanishing Trial: Implications Of The Litigation Matrix, 57 STAN. L. ReV. 1329 (2005). However, there are no facts in the decisions of either AMP1 or AMP2 to support a conclusion that the long DNA
} 
However, Judge Moore concurred in the judgment of Judge Lourie on claim 1, due in large part to prior actions of the USPTO, discussed in part C below.

\section{Physical phenomena and possible alternative formulations}

Judges Lourie and Moore only gave lip service to the Supreme Court's pronouncements that physical phenomena are unpatentable - recognizing that pronouncement but not analyzing it. They did not address whether claim 1, sequences of nucleotide bases "coding for" the BRCA1 polypeptide claimed an unpatentable "physical phenomena," unpatentable subject matter under Chakrabrty and Funk Bros., just as magnetism ${ }^{186}$ and electricity ${ }^{187}$ are unpatentable physical phenomena. If they had addressed that issue and concluded such characteristic was a "physical phenomenon" or "natural phenomenon," wouldn't they have had to conclude that under Chakrabarty and Funk Bros. claim 1 did not constitute patentable subject matter, since claim 1 only includes sequences that code for the polypeptide? But they did not address the issue, and Judge Lourie even rejected consideration of the phenomena of coding for purposes of $\S 101,{ }^{188}$ leaving "physical phenomenon" an empty phrase devoid of meaning in the trilogy of unpatentable subject matter.

Would claim 1 have constituted patentable subject matter if Myriad had revised claim 1 to list the many different base sequences that code for the BRCA1 polypeptide rather than defining the subject matter as base sequences that code for the BRCA1 polypeptide? The argument would be that Myriad was no longer claiming a physical phenomenon, because

segments of claim 1 have additional uses beyond the uses of the native DNA. See infra Part III.B.3. In the Petition, the plaintiffs did dispute what the Majority Opinion relied on as facts. See also Petition at 4 (wherein, plaintiffs did dispute what the Majority Opinion relied on as facts).

${ }^{186}$ See Morse, 56 U.S. at 86; American Bell Tel., 8 S. Ct. at 782; see also text accompanying notes 55-64 above.

${ }^{187}$ Funk Bros., 333 U.S. at 130.

${ }^{188}$ See AMP2, 653 F.3d at 1353. 
"coding for" was no longer in the claim. Regardless of whether the claim was for a physical phenomenon, the analysis in that situation would still have had to consider - under Chakrabarty and Funk - whether the characteristics and uses of the claimed invention would have been markedly different than the native sequences. At least for the long DNA sequences of claim 1 that both Judges Moore and Bryson could not be used for probes or primers, this article would argue that the characteristics and uses would still not be markedly different, so the revised claim would still constitute unpatentable subject matter.

Assuming, as Judge Moore concluded, that shorter isolated DNA segments were markedly different because they could act as probes and primers and the native segments could not, the analysis should separately consider whether claiming the listed sequences pre-empted the physical phenomena and thus remained unpatentable subject matter. For instance, in their concurring opinion in Bilski, Justices Stevens, Ginsburg, Breyer and Sotomayer said, Haws of nature, natural phenomena, and abstract ideas' ... 'are the basic tools of scientific and technological work,' . . . and, therefore, if patented, would stifle the very progress that Congress is authorized to promote, see, e.g., O'Reilly (explaining that Morse‘s patent on electromagnetism for writing would preempt a wide swath of technological developments)." ${ }^{189}$ Professor Kane has argued, "The genetic code does not effectively reside in the public domain if private rights are held in DNA gene sequences, so that biologically meaningful exercises of the genetic code cannot occur without permission from a patent holder. The patenting of genes, therefore, results in constructive preemption of the genetic code, an outcome that conflicts with the Supreme

\footnotetext{
${ }^{189}$ See generally Bilski, 130 S. Ct. at 3253 (quoting in part Diamond, 450 U.S. at 185, Gottschalk, 409 U.S. at 67, and Morse, 56 U.S. at 113). 
Court's dictate that the laws of nature should remain in the public domain, free for all to use."190

A third formulation of claim 1 in the ' 282 patent would produce a still different analysis if, for instance, Myriad claimed a product patent on an isolated DNA segment made by a specific process identified in the claim itself. Under the most recent Federal Circuit authority, Atlantic Thermoplastics Co., Inc. v. Faytex Corp., that claim would only prevent other parties from using or selling the claimed isolated DNA segments made by the exact process identified in the claim. $^{191}$ On the other hand, in an earlier decision the Federal Circuit concluded that in determining infringement, the court should disregard the process limitations. ${ }^{192}$ Assuming the court reviewing the case followed Atlantic Thermoplastics Co., ${ }^{193}$ interpreted and upheld the validity of the process limitations to narrow the scope of the claims, then the arguments about invalidity would be far different. ${ }^{194}$ It is recognized that an inventor can make use of laws of nature, algorithms and other unpatentable subject matter when used in sufficiently concrete

\footnotetext{
${ }^{190}$ Splitting, supra note 33, at 765 (drawing a distinction between the patentability of "tangible DNA molecules" and "exclusionary rights in the sequence information itself, if stored in a computer-readable medium."). See also Rebecca S. Eisenberg, Re-examining the Role of Patents in Appropriating the Value of DNA Sequences, 49 EMORY L.J. 783, 788, 790-91 (2000) [hereinafter Sequences]. However, making the information theoretically available would not address Professor Kane's point that the use of that information could as a practical matter be preempted. Also, the deference Professor Eisenberg would give to the USPTO has the same problems this article argues Judge's Moore's opinion has, and Sequences was written before the United States changed its position to conclude that isolated DNA segments did not constitute patentable subject matter. Of what value is the sequence information if it cannot be used in any practical application?

${ }^{191}$ Atlantic Thermoplastics Co., Inc. v. Faytex Corp., 970 F.2d 834, 841-42, 846-47 (Fed. Cir. 1992) ("a patent applicant could not obtain exclusive rights to a product in the prior art by adding a process limitation to the product claim. A new process, although eligible for a process patent, could not capture exclusive rights to a product already in the prior art....the infringement inquiry for product claims with process limitations focuses on whether the accused product was made by the claimed process or its equivalent.").

${ }^{192}$ Scripps Clinic \& Res. Found v. Genetech, Inc., 927 F.2d 1565, 1583-84 (Fed.Cir. 1991).

${ }^{193}$ For a discussion of this conflict and between Atlantic Thermoplastics and Scripps Clinic and the resultant confusion, see Patent Law at 92-94. See also Aventis Pharmaceuticals, Inc. v. Barr Laboratories, Inc., 335 F.Supp.2d 558, n. 21 (2004) (showing a district court opinion applying the earlier decision, Scripps Clinic, instead of Altantic Thermoplastics).

${ }^{194}$ For one discussion of the scope of product claims compared to product by process claims, see Nelson, supra note 139, at 851 ("purified versions of naturally-occurring proteins. ... These patents typically claim purified versions of products that exist in nature. In these cases, it can be argued that it is stretching the concept of inventing greatly to say that the patentee really invented the products. The true invention seems to be a way of producing those products in a desirable form. But because a product claim is typically broader than one simply on a particular way of making that product, patentees seek-and often obtain-product patents.").
} 
ways. $^{195}$

These alternative formulations of claim 1, however, are not at issue in AMP2. Claim 1 of the '282 patent claims "isolated DNA coding for a BRCA1 polypeptide," directly claiming a physical phenomenon that Judges Moore and Bryson agree have no additional utility beyond the utility of the native DNA. This constitutes unpatentable subject matter under Funk Bros. and Chakrabarty. ${ }^{196}$

\section{Judge Moore's Explanations of her Concurrence with Judge Lourie}

Judge Moore essentially gave three reasons for not concluding "that an isolated DNA sequence that includes most or all of a gene is not patentable subject matter." ${ }^{197}$ She said the following considerations "tipped the scale in favor of patentability": (1) "Congress has, for centuries, authorized an expansive scope of patentable subject matter;" (2) "the United States Patent Office has allowed patents on isolated DNA sequences for decades, and, more generally, has allowed patents on purified natural products for centuries;" and (3) "we must be particularly wary of expanding the judicial exception to patentable subject matter where both settled

\footnotetext{
${ }^{195}$ See, e.g., Diehr, 450 U.S. at 185, 187 ("Our conclusion regarding respondents' claims is not altered by the fact that in several steps of the process a mathematical equation and a programmed digital computer are used . . . the respondents here do not seek to patent a mathematical formula. Instead, they seek patent protection for a process of curing synthetic rubber. Their process admittedly employs a well-known mathematical equation, but they do not seek to pre-empt the use of that equation. .... when a claim containing a mathematical formula implements or applies that formula in a structure or process which, when considered as a whole, is performing a function which the patent laws were designed to protect (e.g., transforming or reducing an article to a different state or thing), then the claim satisfies the requirements of $\S 101 . ")$.

${ }^{196}$ This conclusion is also consistent with the general argument of Demaine and Fellmeth, "[t]he history of Supreme Court and lower court jurisprudence is consistent with the idea that, in order for a substance based upon a naturally occurring phenomenon to constitute an invention, that substance must be substantially transformed from the state in which it naturally occurs. Far from being satisfied with mere isolation and purification" or other pro forma alteration, the patent law long demanded that the function or fundamental character of the natural phenomenon be changed. In biotechnology, this generally means that the biological function of the chemical or tissue at issue must be different from its function in nature.". Linda J. Demaine \& Aaron Xavier Fellmeth, Reinventing the Double Helix: a Novel and Nonobvious Reconceptualization of the Biotechnology Patent, 55 STAN. L. REV. 303,461 (2002). ${ }^{197} A M P 2,653 \mathrm{~F} .3 \mathrm{~d}$ at 1366 . Judge Moore did not state expressly she would otherwise have ruled claim 1 was not patentable subject matter, but suggested such result when she began the quoted sentence with the following phrase: "If I were deciding this case on a blank canvas, I might conclude that an isolated DNA sequence . . . I Id.
} 
expectations and extensive property rights are involved."198

\section{Expansive scope of statutory patentable subject matter vs. Supreme Court limits on that scope}

In commenting that Congress had for over a hundred years authorized an expansive scope of patentable subject matter," 199 Judge Moore overlooked at least half the equation, the duty of the courts to interpret statutes and the Constitution. As the Supreme Court has said, "[O]nce Congress has spoken it is 'the province and duty of the judicial department to say what the law is."'200 Throughout the hundred plus year period Judge Moore referred to, the courts have stated and enforced three exceptions to patentable subject matter under $\S 101$ and its predecessors: abstract ideas, laws of nature and physical/natural phenomena. ${ }^{201}$ The expansive general nature of the Supreme Court's interpretation of $\S 101$ does not give a lower federal court authority to disregard the three exceptions to patentable subject matter established by the Supreme Court or that Court's interpretation of the determination of what constitutes patentable subject matter.

This trilogy of exceptions is consistent with the principle that "Congress may not authorize the issuance of patents whose effects are ... to restrict free access to materials already available." ${ }^{202}$ The exceptions are also consistent with the principle that "absent a discernible signal from Congress, we proceed cautiously when dealing with patents that press on the limits

\footnotetext{
${ }^{198}$ Id. at 1367 .

${ }^{199} I d$.

${ }^{200}$ Chakrabarty, 447 U.S. at 315 (quoting in part Marbury v. Madison, 1 Cranch 137, 177 (1803)).

${ }^{201}$ See Part II.A and B above. In Bilski, the Supreme Court referred to "these well-established exceptions" to the expansive scope of $\S 101$ and said, "Any suggestion in this Court's case law that the Patent Act's terms deviate from their ordinary meaning has only been an explanation for the exceptions for laws of nature, physical phenomena, and abstract ideas." $130 \mathrm{~S}$. Ct. at 3226. See also discussion of Chakrabarty at text accompanying notes 89-105 above. In other words, this trilogy is a restraint on, an exception to, the expansive nature of $\S 101$, and $\S 101$ does not limit the application of this trilogy.

${ }^{202}$ Deere, 383 U.S. at 6.
} 
of the _standard written into the constitution.",203 Certainly patents on isolated DNA segments reside "closer to this boundary between statutory and non-statutory subject matters." ${ }^{204}$ As the Supreme Court expressed it in Bilski, "these exceptions have defined the reach of the statute as a matter of statutory stare decisis going back 150 years." 205

Judge Moore did not apply the applicable law to the facts she found. She said that an isolated full-length gene was too large to be used as a probe or primer, and she did not identify any use for an isolated gene compared to the native gene. ${ }^{206}$ In Chakrabarty, the Supreme Court found patentable subject matter because the "[p]atentee has produced a new bacterium with markedly different characteristics from any found in nature and one having the potential for significant utility." 207 The genetically engineered bacteria would help clean up oil spills where the "native" bacteria did not. ${ }^{208}$ In Funk Bros., the Supreme Court rejected the patent because "the combination of species produces no new bacteria, no change in the six species of bacteria, and no enlargement of the range of their utility." ${ }^{209}$

It was error for Judge Moore to disregard the guidance from the Supreme Court's holdings in Chakrabarty and Funk Bros. and instead rely on the generally expansive nature of $\S 101$ recognized in Chakrabarty.

\footnotetext{
${ }^{203}$ Bilski, 130 S. Ct. at 3253 (quoting in part Deere); ,Graham, 383 U.S. at 6. Judge Moore concluded it was significant that "Congress explicitly declined to implement legislation to 'affect any of those current existing patents. ". AMP2,653 F.3d at 1372. But failure of Congress to act is not a "discernable signal," particularly when many of the patents issued could be valid, given the diversity of facts behind biotech patents. For instance, all three judges in $A M P 2$ concluded the claim regarding cDNA was valid. For instance, even Judge Bryson said, "I agree with the court that the claims to BRCA cDNA are eligible for patenting." Id. at 1378.

${ }^{204}$ MoY, supra note 14, at 5-9 ("Inevitably, some fields of applied technology reside closer to this boundary between statutory and non-statutory subject matters than do others.... Two of these with especially large commercial significance are computer software and biotechnology.").

${ }^{205} 130$ S. Ct. at 3225 (citing Le Roy v. Tatham, 55 U.S. 156, 174 (1853)). See also, Eric J. Rogers, Can You Patent Genes? Yes And No, 93 J.PAT. \& TRADEMARK OFF. SOC'Y 19, 31 (2011).

${ }^{206} A M P 2,653$ F.3d at $1366-67$.

${ }^{207} 447$ U.S. at 310.

${ }^{208} \mathrm{Id}$. at 305.

${ }^{209} 333$ U.S. at 131.
}

PGH. J. TECH. L. \& POL'Y, Vol. 12, No. 3, Fall 2011 


\section{USPTO}

The second example Judge Moore gave was that the US Patent and Trademark Office

had allowed patents on isolated DNA segments for decades." ${ }^{210}$ In his dissent, Judge Bryson rejected this argument, pointing out that the PTO tacks substantive rulemaking authority" on the issue of patentability. ${ }^{211} \mathrm{He}$ added, The comments that the PTO issued at the time of its 2001 guidelines in response to suggestions that isolated human genes were not patentable are, frankly, perfunctory ... [and] I do not regard them as worthy of much weight in the analysis of this complex question." 212

The poor performance of the USPTO supports the position of Judge Bryson not to defer to the practices of the USPTO in this area, even without the decisions in Chakrabarty and Funk Bros. For instance, funding pressures appear to create a USPTO bias to grant patents. ${ }^{213}$ In the Federal Circuit's decision in Bilski, Judge Mayer in dissent said, "Patents granted in the wake of

\footnotetext{
${ }^{210} A M P 2,653$ F.3d at 1367. Interestingly, in a decision a month after $A M P 2$, Classen Immunotherapies, Inc. v. Biogen IDEC, 2011 WL 3835409, (Fed. Cir. August 31, 2011), Judge Moore dissented (*18-26) from the two other judges on the panel that found two patents for a "method of immunizing a mammalian subject" were "eligible under $\S 101$ to be considered for patenting." Id. at *1-2. The USPTO had approved the patents, but Judge Moore gave no apparent deference to these patent grants and did not even mention the USPTO in her dissent. ${ }^{211} A M P 2,653$ F.3d at 1380 (citing Animal Legal Def. Fund v. Quigg, 932 F.2d 920, 930 (Fed.Cir. 1991)).

${ }^{212} A M P 2,653$ F.3d at 1380 (citing Merck \& Co. v. Kessler, 80 F.3d 1543, 1550 (Fed. Cir. 1996)). The Supreme Court expressed the same principle in United States v. Mead Corp., 533 U.S. 218, 228 (2001)("The fair measure of deference to an agency administering its own statute has been understood to vary with circumstances, and courts have looked to the degree of the agency's care ... its consistency . . . formality . . . and relative expertness, (footnote omitted) and to the persuasiveness of the agency's position.").

${ }^{213}$ Melissa F. Wasserman, The PTO's Asymmetric Incentives: Pressure To Expand Substantive Patent Law, 72 OHIO St. L. J. 379, 385-86 (2011) ("The PTO is funded entirely through user fees; the PTO's budget is set to the amount of its projected revenue .... The fees the PTO collects for examining patent applications covers less than one-third of the cost to the Agency for performing this service. In contrast, the post-allowance fees-fees the Agency only collects when it grants a patent-are pure profit, as it costs the Agency next to nothing to perform these services. Thus, the PTO's strong funding incentives to grant patents also results in a systematic driving force, shaping the Agency's views on substantive law in the patent protective direction.").
} 
State Street have ranged from the somewhat ridiculous to the truly absurd." ${ }^{214}$ Quoting Professor Thomas, Professor Dratler reported, "Among the more reviled Patent Office grants has been its 1968 patent on a method of swallowing a pill." ${ }^{215}$ Professors Conley and Makowski reported on the uproar that occurred when the USPTO granted a patent on a cell line from a specific individual from Papua New Guinea, until NIH renounced its patent. ${ }^{216}$ Professors Burk and Lemley have said, "The PTO today is overwhelmed. Patent pendency is much longer than it has ever been, and the problem is getting worse, not better. The PTO is not even keeping pace with new applications." ${ }^{217}$

There is no historical basis for deference to the USPTO on questions of law. Judge Bryson highlighted that prior to the Supreme Court's decision in Chakrabarty, the PTO had determined that microorganisms were not subject to patenting, but the Supreme Court gave no indication that it regarded that view as entitled to deference." 218 He also pointed out that in Chakrabarty, "the Court gave short shrift to the Commissioner's contention (which was made the lead argument in its brief) that the patentability of life-forms was an issue that should be left to Congress." ${ }^{219}$ Similarly showing no deference to the thousands of business method patents the USPTO had granted, ${ }^{220}$ the majority (including Judges Lourie and Moore) of the Federal Circuit in Bilski said, "Neither the PTO nor the courts may pay short shrift to the machine-ortransformation test by using purported equivalents or shortcuts such as a 'technological acts'

\footnotetext{
${ }^{214} 545$ F.3d at 1004 (citing a patented "method of training janitors to dust and vacuum using video displays"; "method for selling expert advice"; and "method for enticing customers to order additional good at a fast food restaurant").

${ }^{215}$ Dratler, Jr., supra note 64, at 304.

${ }^{216}$ Rethinking1, supra note 49, at 301-02.

${ }^{217}$ Dan L. Burk \& Mark A. Lemley, Fence Posts or Sign Posts? Rethinking Patent Claim Construction?, 157 U.PA. L. REV. 1743, 1786 (2009).

${ }^{218} A M P 2,653$ F.3d at 1381.

${ }^{219} \mathrm{Id}$

${ }^{220}$ See In re Bilski, 545 F.3d 943, 992 (Fed. Cir. 1998) (statistics cited by Judge Newman in dissent). 
requirement." 221 Then the Supreme Court in Bilski in turn showed no deference to the USPTO or the Federal Circuit. ${ }^{222}$

Indeed, the Federal Circuit has expressly ruled that the issue of patentable subject matter is a question of law and that it decides those questions de novo without deference. ${ }^{223}$ This is not an isolated ruling: "the Federal Circuit has repeatedly stated that it grants no deference whatsoever to PTO legal interpretations." ${ }^{224}$ Particularly since the three exclusions from patentable subject matter are the creation of the courts, not statutes, and there is no reason to assume the USPTO has more expertise than the courts on this crucial issue of law at the intersection of patent law and life.

Indeed, the United States essentially concluded that the defendant USPTO practice has been wrong with respect to claim 1. On October 29, 2010, the United States Government filed a "Brief for the United States as Amicus Curiae in Support of Neither Party" (the "US Brief"). ${ }^{225}$ The US Brief said, "the United States has concluded that isolated but otherwise unaltered genomic DNA is not patent-eligible subject matter under 35 U.S.C. $§ 101 . " 226$ The US Brief

${ }^{221} I d$. at 964 .

${ }^{222}$ In fact, the only reference to "Trademark Office" in the Supreme Court's decision in Bilski appears to be the following footnote 5 in Justice Stevens concurring opinion: "Although a few patents issued before 1952 that related to methods of doing business, see United States Patent and Trademark Office, Automated Financial or Management Data Processing Methods, http://www.uspto.gov/web/menu/busmethp/index.html (last visited Oct. 11, 2011). These patents were rare, often issued through self-registration rather than any formalized patent examination, generally were not upheld by courts, and arguably are distinguishable from pure patents on business methods insofar as they often involved the manufacture of new objects. See In re Bilski, 545 F.3d 943, 974, and n. 18 (C.A.Fed.2008) (case below) (Dyk, J., concurring); Pollack 74-75; Walterscheid, To Promote the Progress 243. 130 S. Ct. at 3246.

${ }^{223}$ In re Comiskey, 554 F.3d 967, 975 (Fed. Cir. 2009)("It is well-established that 'whether the asserted claims . . . are invalid for failure to claim statutory subject matter under 35 U.S.C. $\S 101$, is a question of law which we review without deference,"' quoting in part AT \& T Corp. v. Excel Commc'ns, Inc., 172 F.3d 1352, 1355 (Fed.Cir.1999)).

${ }^{224}$ Stuart Minor Benjamin Arti K. Rai, Who's Afraid of the APA? What the Patent System Can Learn From Administrative Law, 95 GEO. L. J. 269, 299-300 and nn. 159-162 (2007) (citing, among other cases, Arnold Partnership v. Dudas, 362 F.3d 1338, 1340 (Fed. Cir. 2004)(" This court reviews statutory interpretation, the central issue in this case, without deference").

${ }^{225}$ See 2010 WL 4853320 (2011) [hereinafter US Brief].

${ }^{226} I d$. at $* 18$. 
acknowledged that this position was different than past practice of the USPTO, but explained that the District Court's decision in AMP1 had "prompted the United States to reevaluate the relationship between such patents and the settled principle under Supreme Court precedent that the patent laws do not extend to products of nature."227 The United States concluded that the "Court should ... a affirm the district court's conclusion that the claims encompassing isolated human genomic DNA are invalid." 228

In short, the history of the USPTO and existing judicial decisions do not support giving deference to the fact that the USPTO has granted many patents to various forms of isolated DNA segments. Moreover, the position of the United States government does not support affirming the position of the USPTO on claim 1. The other litigation, "settled expectations," and "property rights" mentioned by Judge Moore and discussed next provide no more support for his Concurring Opinion.

\section{Other litigation, settled expectations and property rights}

\section{Other litigation}

Judge Moore also suggested that -laims similar to the ones at issue in this case have been the focal point of important litigation," citing Amgen, Inc. v. Chugai Pharmaceutical Co. ${ }^{229}$ and Amgen, Inc. v. Hoechst Marion Russel, Inc. ${ }^{230}$ However, as mentioned above, patentable subject matter was not decided in Chugai, ${ }^{231}$ nor was it decided in Hoechst Marion Russel. ${ }^{232}$

\footnotetext{
${ }^{227} I d$.

${ }^{228} I d$. at $* 37$. The United States asked that the Federal Circuit "reverse the district court"s invalidation of the composition claims that are limited to cDNAs and similar man-made constructs."

${ }^{229}$ AMP2, 653 F.3d at 1367 (citing Amgen, Inc. v. Chugai Pharmaceutical Co., 927 F.2d 1200 (Fed. Cir. 1991).

${ }^{230} 126$ F.Supp.2d 69 (D.Mass. 2001).

${ }^{231}$ See supra text accompanying note 116. Cf., Conley, supra note 184 at 116 ("That Amgen's patent was directed to statutory subject matter was taken for granted and not at issue in the case.").
} 
As mentioned above in the discussion of Intervet, in 2010 Judge Dyk observed that neither the Supreme Court nor the Federal Circuit had "directly decided the issue of the patentability of isolated DNA molecules" and then gave reasons supporting the argument that such molecules did not constitute patentable subject matter. ${ }^{233}$ Judges Prost and Bryson said, "We do not address the issues of validity and non-patentable subject matter discussed by the dissent because these issues were not addressed by the district court or raised on appeal." ${ }^{234}$ The panel instructed the District Court on remand to determine "whether the accused product infringes the asserted claims of the '601 patent," ${ }^{235}$ without any direction to consider whether the claim constituted patentable subject matter.

In other words, if the parties do not raise the issue of patentable subject matter, the courts generally do not consider it. ${ }^{236}$ In fact, the parties in patent litigation often seem to avoid raising claims of unpatentable subject matter and instead challenge patents on other grounds, perhaps because each of them wants their own product patents for unpatentable subject matter and do not want to rock the boat on this issue. ${ }^{237}$

\footnotetext{
${ }^{232}$ The issues in Hoechst Marion Russel were claim construction, definiteness, inequitable conduct, obviousness, enablement, and written description, not patentable subject matter. 126 F.Supp.2d at 137-66.

${ }^{233}$ See infra p. 19 discussing Intervet.

${ }^{234}$ Intervet Inc., 617 F.3d at n.4.

${ }^{235} I d$. at 1292.

${ }^{236}$ In what became a companion case to Chakrabarty, In re Bergy, the Federal Circuit held that a claim for a biologically pure culture of the microorganism Streptomyces vellosus was patentable. ${ }^{236} 563$ F.2d 1031 (Fed. Cir. 1977), cert. granted and judgment vacated, 438 U.S. 902 (1978) for reconsideration in light of Parker v. Flook; 596 F. 2d 952 (Fed. Cir. 1979), cert. granted and Bergy dismissed as moot in Diamond v. Chakrabarty, 444 U.S. 1028 (1980). The patent examiner had rejected the patent application on the ground that the claim did not constitute patentable subject matter because the microorganism was a product of nature." The United States Patent and Trademark Board of Appeals affirmed the rejection of the application, but on the ground that $\S 101$ precluded the grant of patents for living organisms, a slightly different issue. Id. at 1033-1034. When the rejection was appealed to the U.S. Court of Custom and Patent Appeals, that court said, We consider the product-of-nature issue to have been abandoned and no longer in the case." Id. at 1035. On rare occasions, courts have raised the issue of patentable subject matter sua sponte; see Ineligibility, supra note 4, at 532-535.

${ }^{237}$ Ineligibility, supra note 4, at 528-529 ("Many patent disputes are between similarly situated competitors, who may be in conflict over a particular patent, but in agreement regarding the general eligibility of subject matter in a particular field. The consequences of a determination that patentable subject matter does not exist might extend
} 


\section{Settled Expectations}

Judge Moore referred to the "settled expectations of the biotechnology industry" and then said, The type of fundamental alteration in the scope of patentable subject matter argued in this case risk[s] destroying the legitimate expectations of inventors in their property," quoting in part Festo Corp. v. Shoketsu Kinzoku Kogyo Kabushiki Co. ${ }^{238}$ Yet that quote from Festo is misleading, because Festo involved "the doctrine of equivalents and the rule of prosecution history estoppel [that] are settled law"239 that had been established through a series of Supreme Court holdings, ${ }^{240}$ not practices by administrative agencies such as the USPTO. As the Court observed in Festo, "patent prosecution occurs in the light of our case law. Inventors who amended their claims under the previous regime had no reason to believe they were conceding all equivalents. ....There is no justification for applying a new and more robust estoppel to those who relied on prior doctrine." ${ }^{241}$ Festo simply is an example of the Supreme Court following the principle of stare decisis and not rejecting its prior holdings.

Consistency in judicial rulings - stare decisis - is an important principle of jurisprudence in this country, but avoiding decisions based on public opinion is also important. In Planned Parenthood of Southeastern Pennsylvania v. Casey, ${ }^{242}$ the Supreme Court said that "the very

beyond the particular patent in suit, resulting in hesitation on the part of either party (or the courts) to raise the issue for fear of sector-wide consequences."). See also Splitting, supra note 33, at 726 ("[A]ssertions of lack of patentable subject matter as a ground for invalidity are seldom raised during patent litigation . . . Although the most likely reason for this absence is that the issue is not germane to most inter parties disputes, patent litigation also often involves similarly situated competitors, neither of which may be interested in raising an issue with implications beyond the patent in suit. When litigation results in a determination of a lack of patentable subject matter, nonparties may be affected if patents to an entire class of inventions are called into question.").

${ }^{238}$ AMP2, 653 F.3d at 1368 (quoting Festo Corp. v. Shoketsu Kinzoku Kogyo Kabushiki Co., 535 U.S. 722,739 (2002)).

${ }^{239}$ Festo, 535 U.S. at 739.

${ }^{240}$ See, e.g., Warner-Jenkinson Co. v. Hilton Davis Chemical Co., 520 U.S. 17 (1997) and Graver Tank \& Mfg. Co.

v. Linde Air Products Co., 339 U.S. 605 (1950).

${ }^{241}$ Festo, 535 U.S. at 739.

${ }^{242}$ Planned Parenthood of Southeastern Pennsylvania v. Casey, 505 U.S. 833, 854 (1992). 
concept of the rule of law underlying our own Constitution requires such continuity over time that a respect for precedent is, by definition, indispensable." ${ }^{143}$ The Court recognized that in very limited situations courts could diverge from precedent, ${ }^{244}$ but the Court emphasized the importance of relying on past holdings and not public passions: "The Court must take care to speak and act in ways that allow people to accept its decisions on the terms the Court claims for them, as grounded truly in principle, not as compromises with social and political pressures having, as such, no bearing on the principled choices that the Court is obliged to make."245

Judge Moore said, The settled expectations of the inventing community with respect to isolated DNA claims are built upon . . . judicial precedent, such as Parke-Davis and Merck."246 To cite these two purification cases for "settled expectations" and not other historical cases concerning "purification" was selective - even if expectations were relevant. In an earlier part of her opinion, for instance, Judge Moore cited In re Marden, in which the court held that "[u]ranium is a product of nature, and the appellant is not entitled to a patent on the same, or upon any of the inherent natural qualities of that metal." 247 She also cited General Electric $v$. DeForest Radio, Co., in which the Third Circuit held that purified tungsten did not constitute patentable subject matter, even though purified tungsten was ductile, whereas in nature it was brittle. ${ }^{248}$ If settled expectations were relevant, Marden and General Electric would have helped to create expectations that isolated DNA segments were not patentable subject matter.

\footnotetext{
${ }^{243} I d$.

${ }^{244}$ Id. at $854-869$.

${ }^{245} I d$. at $865-866$.

${ }^{246} A M P 2,653$ F.3d at 1368. See discussion of these two cases at text accompanying notes $112-115$ above. It is difficult to reconcile Judge Moore's assertion that Parke-Davis helped create "settled expectations" with the Majority Opinion, in which Judge Lourie distinguished Parke-Davis and said the In Re Marden cases were "similarly inapposite." AMP2, 653 F.3d at 1352. How can a case that is not relevant according to Judge Lourie help create settled expectations?

${ }^{247}$ In re Marden, 47 F.2d 957, 957 (CCPA 1931) (cited in AMP2, 653 F.3d at 1360).

${ }^{248}$ Gen. Elec. Co. v. De Forest Radio Co., 28 F.2d 641, 643 (3d Cir. 1928) (see discussion of General Electric at text accompanying notes 109-111 above).
} 
In fact, scholars have recognized from 1990 onward that whether isolated DNA segments constituted patentable subject matter was an open question. In 1990, Professor Eisenberg recognized that "the patents may still be vulnerable to challenges to their validity in the courts." ${ }^{249}$ In 2003, Professors Conley and Makowski wrote that "the product of nature doctrine still has a meaningful role to play in the protection of the biological public domain," and that "there is no warrant in the history of the product of nature doctrine for allowing it to be circumvented by the mere incantation of some combination of the words 'isolated,' 'purified,' and 'synthesized."'250 In 2004, Professor Kane wrote, "The patenting of genes . . . results in constructive preemption of the genetic code, an outcome that conflicts with the Supreme Court's dictate that the laws of nature should remain in the public domain, free for all to use."251

To suggest that courts should try to determine what expectations in the community are on subjects that no court has ruled on seems to turn stare decisis on its head. Courts should issue principled decisions removed from public passions. Judge Bryson said, "Although my colleagues believe our analysis of the legal question in this case should be influenced by purported expectations of the inventing community based on the PTO's past practice of issuing patents on human genes, that is in effect to give the PTO lawmaking authority that Congress has not accorded it." ${ }^{252}$

\section{Property Rights}

Judge Moore referred to "extensive property rights," ${ }^{253}$ but patents are necessarily subject

\footnotetext{
${ }^{249}$ Rebecca S. Eisenberg, Patenting the Human Genome, 39 EMORY L. J. 721, 721-22 and n. 4 (1990).

${ }^{250}$ Rethinking 2, supra note 102 at 398.

${ }^{251}$ Splitting, supra note 33, at 765.

${ }^{252}$ AMP2, 653 F.3d at 1381 .

${ }^{253}$ Id. at 1367 .
} 
to challenge and - where appropriate - invalidation. ${ }^{254}$ If the Federal Circuit had affirmed the District Court's $A M P 2$, that would not have meant the patents of other holders of product patents for isolated DNA would necessarily have been invalidated. There would have to have been litigation challenging the other patents, and litigants who had unsuccessfully challenged the patents in the past would be barred by res judicata from re-litigating the issue of patentable subject matter. ${ }^{255}$ There probably would have been many patents on isolated DNA that would not have been challenged at all. Indeed, other patented isolated segments of DNA might have significantly different characteristics and additional utility over the native DNA and therefore constitute patentable subject matter under Chakrabarty and Funk Bros. Affirmance of the District Court's opinion would not have eliminated any property rights.

It is appropriate for a court to consider the effect on property rights established by prior judicial decisions when the court is considering whether to change an established judicial policy, but the Federal Circuit did not face such a situation in AMP2. In contrast, in Bilski the Supreme Court said, "'[W]e must proceed cautiously when we are asked to extend patent rights' into an area that the Patent Act likely was not 'enacted to protect' . . lest we create a legal regime that Congress never would have endorsed, and that can be repaired only by disturbing settled property rights." 256 The reference to "settled property rights" in Bilski was referring to property

\footnotetext{
${ }^{254} 35$ U.S.C. $§ 282$ provides, "A patent shall be presumed valid" and "The burden of establishing invalidity of a patent ... shall rest on the party asserting such invalidity." In Microsoft Corp. v. i4i Limited Partnership, 131 S. Ct. 2238, 2242 (2011), the Supreme Court held that "§ 282 requires an invalidity defense [to a claim of infringement] to be proved by clear and convincing evidence." In contrast, in trademark law, continuous use of a trademark for 5 years subsequent to registration of the mark can make that mark incontestable for most purposes. See 15 U.S.C. § 1065. If Congress had wanted patent grants to be incontestable and not subject to challenge, they could have said so.

${ }^{255}$ For a discussion of res judicata in patent litigation, see Edmund J. Haughey, Consider The Possibility Of Future Claim Preclusion Before Filing A Complaint For Patent Infringement, 21 No. 4 INTELL. PROP. \& TECH. L.J. 1 (2009).

${ }^{256}$ Bilski, 130 S. Ct. at 3250 (citing Parker, 437 U.S. at 596). See also Nese, supra note 5, at 168 ("The recently decided Bilski decision marks a notable change in the court's interpretation of patent-eligible subject matter as
} 
rights established by the courts, not presumptions of validity created by the USPTO and expressly subject to challenge by statute. ${ }^{257}$

There is no basis for giving patent holders the benefit of their gamble ${ }^{258}$ in applying for and obtaining patents on DNA segments when there have been no court decisions holding that isolated DNA segments constituted patentable subject matter.

\section{Summary}

Of what value are facts, case law and stare decisis if a court can disregard them? The opinion of Judge Moore gives deference to many things in the past, but not the facts or the law. On the law, in Chakrabarty the Supreme Court showed that in determining patentable subject matter, a court should consider if the invention has markedly different characteristics and if there are potentially significant additional uses beyond what exists in nature. ${ }^{259}$ On the facts, Judge Moore essentially agreed that the isolated segments of claim 1 did not have different uses than the native segments. ${ }^{260}$ This combination of law and facts should have resulted in his joining with Judge Bryson to affirm the District Court's ruling on claim 1.

applied to process patens and may even partially limit the broad eligibility interpretations rooted in Chakrabarty."). The Federal Circuit's decision in Bilski was stricter than the Supreme Court's decision in Bilski, since the Federal Circuit's decision limited process patents to the "machine or transformation" test. $545 \mathrm{~F} .3 \mathrm{~d}$ at 966 . In contrast, the Supreme Court in Bilski ruled that "the machine-or-transformation test is a useful and important clue, an investigative tool, for determining whether some claimed inventions are processes under $\S 101$. The machine-ortransformation test is not the sole test for deciding whether an invention is a patent-eligible 'process."' $130 \mathrm{~S}$. Ct. at 3227.

${ }^{257}$ In Parker, the Court said "[i]t is our duty to construe the patent statutes as they now read, in light of our prior precedents, and we must proceed cautiously when we are asked to extend patent rights into areas wholly unforeseen by Congress." 437 U.S. at 596. The Court in Parker also quoted Deepsouth Packing Co. v. Laitram Corp., 406 U.S. 518,531 (1972) (-We would require a clear and certain signal from Congress before approving the position of a litigant who, as respondent here, argues that the beachhead of privilege is wider, and the area of public use narrower, than courts had previously thought. No such signal legitimizes respondent's position in this litigation.”).

${ }^{258}$ See, e.g., Nese, supra note 5, at 152-53 ("the United States Patent and Trademark Office (PTO) was flooded with applications relating to genes and genetic testing methods .... During this rush, lots of tand-grabbing" occurred without actually knowing what was being claimed.").

${ }^{259}$ See Chakrabarty, 447 U.S. at 309-10.

${ }^{260}$ AMP2, 2011 WL 3211513 at 122-24. 
Deference instead to the past actions of the USPTO on this question of law is without judicial support, particularly in light of the holdings in Chakrabarty and Funk Bros and the three exceptions to patentable subject matter that "have defined the reach of the statute [§101] as a matter of statutory stare decisis going back 150 years," ${ }^{261}$ Trying to speculate on the expectations of certain citizens and not others has lowered the Federal Circuit in AMP2 to a poll taker, not a judicial body bound by Chakrabarty and Funk Bros. ${ }^{262}$

\section{In Addition to Stare Decisis, Patent Policies Support Funk and Chakrabarty}

The Supreme Court can of course not follow precedent if it so chooses. However, the basic balancing considerations of patent law support Funk Bros. and Chakrabarty and do not provide a reason for the Supreme Court to disregard precedent.

The fundamental balancing task for patent law involves economic regulation and incentives at one end to increase innovation and benefits to society while maintaining personal freedom at the other end. ${ }^{263}$ Thomas Jefferson talked of the difficulty of drawing the right

\footnotetext{
${ }^{261}$ Bilski, 130 S. Ct. at 3225 . See also Rogers, supra note 205 , at 31.

${ }^{262}$ The Plaintiffs and Appelllees before the Federal Circuit in AMP2 in the litigation are The Association for Molecular Pathology, The American College of Medical Genetics, The American Society for Clinical Pathology, The College of American Pathologists, Haig Kazazian, MD, Arupa Ganguly, PhD, Wendy Chung, MD, PhD, Harry Ostrer, MD, David Ledbetter, PhD, Stephen Warren, PhD, Ellen Matloff, M.S., Elsa Reich, M.S., Breast Cancer Action, Boston Women's Health Book Collective, Lisbeth Ceriani, Runi Limary, Genae Girard, Patrice Fortune, Vicky Thomason, and Kathleen Raker. See Brief of Appellees in AMP2 at 2010 WL 5311467. Their Brief said, "The patenting of human genes violates long-establsihed Supreme Court precedent that prohibits the patenting of laws of nature, natural phenomena, products of nature, and abstract ideas." 2010 WL 5311467 at *37. Did the expectations of this group of scientists and patients not count? The answer is their expectations, and the expectations of others that are not based on judicial holdings, should not count under the rule of law. Thus, it is irrelevant that the Chief Policy Office of BIO Ventures for Global Health wrote before the decision in AMP2 "that not only are DNA patents not required for innovation in the development of gene-based molecular diagnostics, but also they actually hinder the advancement and clinical adoption of personalized medicine." See Robertson, supra note 9 , at 399 .

${ }^{263}$ Professor Dratler said, "[i]t is well understood that antitrust law and patent law are just two sides of the same coin-the coin of economic law. The English recognized this point nearly four centuries ago, when the Parliament adopted the Statute of Monopolies ... That statute imposed a general prohibition on monopoly ... much like our Sherman Act ... but it allowed patents as an exception to the general rule.". See Dratler, supra note 64, at 302.
} 
balance in 1813: "[c]onsidering the exclusive right to invention as given not of natural right, but

for the benefit of society, I know well the difficulty of drawing a line between the things which are worth to the public the embarrassment of an exclusive patent, and those which are not." 264

The Supreme Court has explained that the "basic quid pro quo contemplated by the Constitution and the Congress for granting a patent monopoly is the benefit derived by the public from an invention with substantial utility." ${ }^{265}$ However, since neither Judge Moore nor Judge Bryson found any additional utility in the isolated segments of claim $1,{ }^{266}$ and since Judge Lourie thought utility was irrelevant to patentable subject matter, ${ }^{267}$ the policy of promoting substantial increases in utility could not have justified the Federal Circuit overlooking the requirements of Funk Bros. and Chakrabarty to compare the functioning of the "invention" with the functioning of the analogous product in nature.

The Patent Clause offers "a right of exclusion for a limited period as an incentive to inventors to risk the often enormous costs in terms of time, research, and development." ${ }^{268}$ The justification for this right of exclusion is that the resultant "productive effort thereby fostered will

\footnotetext{
${ }^{264}$ August 13, 1813 letter of Thomas Jefferson to Isaac McPherson, http://www.let.rug.nl/usa/P/tj3/writings/brf/jefl220.htm (last visited on Aug. 29, 2011).

${ }^{265}$ Brenner v. Manson, 383 U.S. 519, 534 (1966). Judge Moore might argue that the reference to "utility" in Brenner refers to "utililty" under $\S 101$ and not patentable subject matter (also under $\S 101$ ) and that are separate concepts. Of course, the single sentence of $\S 101$ does not suggest that "utility" and patentable subject matter are separate considerations: "Whoever invents or discovers any new and useful process, machine, manufacture, or composition of matter, or any new and useful improvement thereof, may obtain a patent therefor, subject to the conditions and requirements of this title." Moreover, in Chakrabarty, where the only question was patentable subject matter, the Supreme Court highlighted its consideration of utility. See text accompanying notes 89-99 above. As Professor Feldman recently said, "Patent law has become too segmented in thinking about the elements of patentability, and we risk losing the ability to see the system as a dynamic whole, with all of the parts working together. In particular, it makes little sense to think about patentable subject matter in isolation from the other elements of patentability and limiting principles of patent law. Rather, one should analyze patentable subject matter in the following manner: considering the limitations of the patent system as a whole, are we likely to have preemption problems with the subject matter of this patent?" Robin Feldman, Whose Body Is It? Human Cells and the Strange Effects of Property and Intellectual Property Law, 63 STAN. L. REV. 1377, 1391-92 (2011). Chakrabarty and Funk mandate consideration of function/use.

${ }^{266}$ See infra Part III.B.3.

${ }^{267}$ See infra Part III.B.2.

${ }^{268}$ Kewanee Oil Co. v. Bicron Corp., 416 U.S. 470, 480 (1974).
} 
have a positive effect on society through the introduction of new products and processes of manufacture into the economy, and the emanations by way of increased employment and better lives for our citizens. In return for the right of exclusion-this _eward for inventions ${ }^{\star} \ldots$ the patent laws impose upon the inventor a requirement of disclosure." ${ }^{269}$ In other words, the Patent Clause reflects a balance between the need to encourage innovation and the avoidance of monopolies which stifle competition without any concomitant advance in the _Progress of Science and useful Arts." ${ }^{270}$

In the area of basic scientific research, the most thorough investigation by distinguished scientists on the effects of patents in this area shows that patents on basic genetic discoveries have not increased basic genetic research and have probably harmed the availability of genetic testing. ${ }^{271}$ In 2010 in a letter to the Secretary of Health and Human Services, the Chair (the "Chair") of the Advisory Committee on Genetics, Health, and Society ("SACGHS Report") summarized the findings of the committee, saying that "patents on genetic discoveries do not appear to be necessary for either basic genetic research or the development of available genetic tests." 272 The Chair added, "[p]atents have been used to narrow or clear the market of existing tests, thereby limiting, rather than promoting availability of testing. ${ }^{273}$ The Chair concluded, "The substantial number of existing patents on genes and methods of diagnosis also pose a threat to the development of multiplex testing, parallel sequencing, and whole-genomic sequencing, the

\footnotetext{
${ }^{269} I d$.

${ }^{270}$ Bonito Boats, Inc. v. Thunder Craft Boats, Inc., 498 U.S. 141, 146 (1989).

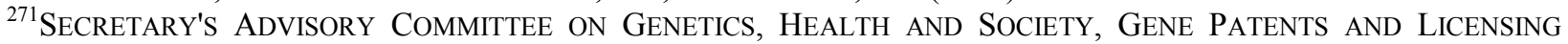
Practices AND THEIR IMPACT ON PATIENT ACCESS to GenetiC TESTS, (2010) [hereinafter SACGHS Report] available at http://oba.od.nih.gov/oba/sacghs/reports/SACGHS patents_report_2010.pdf. The Roster and Ex Officio Members of SACGHS are listed at pp. i-iv.

${ }^{272}$ Steven Teutsch, Cover letter to SECRETARY'S ADVISORY COMMITTEE ON GENETICS, HEALTH AND SOCIETY, GENE PATENTS AND LiCENSING PRACTICES AND Their IMPACT On PATIENT ACCESS to GenetiC Tests (2010).

${ }^{273} I d$.
} 
areas of genetic testing with the greatest potential future benefits." ${ }^{274}$

The Chair's letter and the following SACGHS Report findings are consistent with not expanding the reach of patent law to weaken the exclusion from patentable subject matter of physical phenomena, laws of nature and abstract ideas: "The underlying rationale for the exclusions is that scientific advances depend on an available substrate of basic knowledge, and that, therefore, patenting the intellectual foundation of a field has an adverse effect on its progress:" 275

- $\quad$ "[T]he prospect of patent protection of a genetic research discovery does not play a significant role in motivating scientists to conduct genetic research. Scientists typically are driven instead by factors such as the desire to advance the understanding, the hope of improving patient care though new discoveries, and concerns for their own career development." 276

- "Although the patent law requirements of disclosure and description of a claimed invention is meant to expand the public storehouse of knowledge and stimulate follow-on research, there is evidence to suggest that patents on genes discourage follow-on research." 277

- $"[\mathrm{P}]$ atents are not needed to encourage disclosure in industry because a new health care product or service will not be accepted by the clinical community unless there is disclosure . . . "278

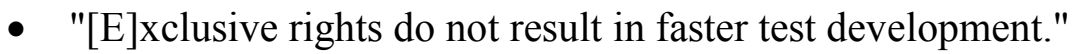

- "Where patents and licensing practices have created a sole provider of a genetic test, patient access to those tests has suffered in a number of ways." 279

Consistent with the SACGHS Report, the Chief Policy Officer of BIO Ventures for Global concluded that "not only are DNA sequence patents not required for innovation in the development of gene-based molecular diagnostic, but also they actually hinder the advancement

${ }^{274} I d$.

${ }^{275}$ Patenting, supra note 21, at 4-5.

${ }^{276}$ SACGHS Report, supra note 271 , at 1.

${ }^{277} I d$. at 2.

${ }^{278} \mathrm{Id}$..

${ }^{279} I d$. at 3 . 
and clinical adoption of personalize medicine." ${ }^{280}$ In short, the economic goals of patent law do not support an increase in the reach of patent law to patents on isolated DNA segments.

The final branch of the patent law balance -- preserving public access to the building blocks of knowledge and the benefits of those building blocks - does not support extending the patent monopoly to isolated DNA segments. ${ }^{281}$ As the Supreme Court said in Deere, "Congress may not authorize the issuance of patents whose effects are to remove existent knowledge from the public domain, or to restrict free access to materials already available."282 Maintaining this public domain is the reason for the trilogy of exceptions to patentable subject matter that the Supreme Court has consistently enforced: "The concepts covered by these exceptions are 'part of the storehouse of knowledge of all men . . . free to all men and reserved exclusively to none."'283 Professors Nard, Barnes and Madison have said, "[o]n the one hand, patent law strives to promote technologic innovations through proprietary rights, and, on the other hand, to provide legal space or access to those innovations." 284 Professor Mueller has said, "[p]atent rights should be understood as carefully limited exceptions to the general rule of free and open competition through imitation."285 Patents for isolated DNA segments threaten to eviscerate the public domain for the building blocks of basic scientific research that are "free to all men and reserved

\footnotetext{
${ }^{280}$ Robertson, supra note 9, at 68. In Chakrabarty, the Supreme Court observed, "The large amount of research that has already occurred when no researcher had sure knowledge that patent protection would be available suggests that legislative or judicial fiat as to patentability will not deter the scientific mind from probing into the unknown any more than Canute could command the tides." 447 U.S. at 317.

${ }^{281}$ See, e.g., Feldman, supra note 265, at 1385 ("Our enthusiasm and appreciation for the miraculous advances of science should not blind us to the necessity of thinking through the interests of the people whose cells provide the raw materials, nor should it obviate the necessity of ensuring that those raw materials are properly obtained.").

${ }^{282}$ Deere, 383 U.S. at 6.

${ }^{283}$ Bilski, 130 S. Ct. at 3225 (quoting in part Funk Bros., 333 U.S. at 130).

${ }^{284}$ Craig Allen NARD, DaVid W. Barnes and Michael J. Madison, The LaW of InTEllectual Property 10 (2d. ed 2010).

${ }^{285}$ JANice M. Mueller, PATENT LaW 8 (3d ed. 2009).

PGH. J. TeCh. L. \& POL'Y, Vol. 12, No. 3, Fall 2011 
exclusively to none."'286

In other word, the basic policies behind patent law do not warrant a rejection or narrowing of 150 years of stare decisis or the more recent decisions of Funk Bros. and Chakrabarty.

\section{CONCLUSION}

"Our role is to interpret the law that Congress has written in accordance with the governing precedents. I would do so and would affirm the district court's rulings . . ." - Judge Bryson in dissent in AMP2. ${ }^{287}$

Claim 1 of Myriad's '282 patent claims: "An isolated DNA coding for a BRCA1 polypeptide, said polypeptide having the amino acid sequence set forth in SEQ ID NO:2."288 Myriad does not list all the isolated sequences it claims to have a right to monopolize, but instead claims a patent on the physical phenomena itself - all DNA segments that code for the BRCA1 polypeptide, ${ }^{289}$ even the sequences Myriad has not identified and even if the person created the sequences through a method or methods not contemplated by Myriad. ${ }^{290}$

The Supreme Court has stated that "Congress may not authorize the issuance of patents whose effects are to remove existent knowledge from the public domain, or to restrict free access to materials already available." ${ }^{291}$ Unfortunately, in AMP2, the Federal Circuit - not Congress has done just that and has given Myriad a wall to restrict free access to materials that have been both inside and available to, humans for centuries. ${ }^{292}$

\footnotetext{
${ }^{286}$ Bilski, 130 S. Ct. at 3225 (quoting in part Funk Bros., 333 U.S. at 130).

${ }^{287}$ AMP2, 653 F.3d at 1381.

${ }^{288}$ Patent No. 5,747,282 at [153-154] (filed May 5, 1998).

${ }^{289}$ See supra note 30 .

${ }^{290}$ Morse, $56 \mathrm{~S}$. Ct. at 112 (Claiming the coding power of DNA segments seems analogous to the rejected eighth claim in Morse, in which Morse claimed the "motive power" of "electronic or galvanic current").

${ }^{291}$ Deere, 383 U.S. at 6.

${ }^{292} C f$., Brief for the Southern Baptist Convention as Amicus Curiae in Support of Plaintiffs-Appellees and Arguing 
The isolated DNA segments of claim 1 do exactly the same coding as the do the native segments - nothing more; nothing less. ${ }^{293}$ The segments of claim 1 do not act as primers or probes,${ }^{294}$ so they do not have markedly different characteristics or utility than native DNA, ${ }^{295}$ which the Supreme Court in Funk Bros. ${ }^{296}$ and Chakrabarty ${ }^{297}$ showed that courts must consider. The effect of the sequence of the nucleotide bases is a physical phenomenon that Myriad has not created but has captured in its claim. Judges Lourie and Moore disregarded Chakrabarty and Funk Bros. in AMP2.

The Supreme Court should accept cert. and reverse the decision in AMP2 on claim $1 .^{298}$ The Court should reject and tear down this patent wall so such DNA segments are readily available to all scientists who need them for research and to all human beings who need them for treatment.

for Affirmance at 2011 WL 585712 at *2 ("The patenting of human genes is an affront to humanity. .... Basic principles of patent law provide that products of nature and laws of nature are unpatentable subject matter. Whether viewed from the secular belief that gene sequences and correlations are part of the prior art created by nature--or from the religious belief that they were created by a divine Creator--the result is the same. Amicus Curiae the Southern Baptist Convention urge this Court to uphold the District Court's decision and invalidate the Myriad patent claims at issue.").

${ }^{293}$ See Conley, supra note 184, at 84; see also supra note 172.

${ }^{294} A M P 2,653$ F.3d at 1366; see Conley, supra note 184, at 120.

${ }^{295}$ AMP2, 653 F.3d at 1366; see Conley, supra note 184, at 120.

${ }^{296}$ See supra text accompanying notes 80-87 above.

${ }^{297}$ See supra text accompanying notes $89-99$ above

${ }^{298}$ This article takes no position on claims 2 or 5 of the '282 patent. 


\section{APPENDIX: BIOCHEMISTRY ${ }^{299}$ THE GENETIC CODE AND THE MYRIAD PATENTS}

\section{DNA, chromosomes and genes}

DNA (deoxyribonucleic acid) is a long molecule believed to be found in every single cell of every living organism. ${ }^{300}$ Every "DNA molecule is made up of repeating units of four nucleotide bases adenine ("A"), thymine ("T"), cytosine ("C"), and guanine ("G") - which are covalently linked, or bonded together via a sugarphosphate or phosphodiester backbone." ${ }^{301}$ DNA typically consists of a double helix of two intertwined strands of DNA chemically bound to each other through base pairing. The adenine on one strand of DNA always binds to the thymine on the other strand, and the guanine on one strand always binds to the cytosine on the other strand. ${ }^{302}$ Two bases form as rungs of the double helix backbones, with adenine pairing with thymine, and cytosine pairing with guanine. ${ }^{303}$

DNA dictates the functioning of each individual cell by directing the making of proteins at certain times and amounts. ${ }^{304}$ Cells are classified as either eukaryotic (including the cells in plants, animals, fungi and protists) or prokaryotic (e.g., bacteria). ${ }^{305}$ In eukaryotic cells, most of the cell's DNA is found in the nucleus of the cell, organized into units called chromosomes. ${ }^{306}$ The chromosomes of human beings contain the human genetic code, or genome, consisting of approximately 25,000 genes and 3 billion base pairs, that dicate the creation of the proteins in that individual. ${ }^{307}$

\footnotetext{
${ }^{299}$ H. Robert Horton, ET AL., Principles of Biochemistry 1, (4th ed. 2006) ("Biochemistry is the study of the molecules and chemical reactions of life. It is the discipline that uses the principles and language of chemistry to explain vbiology at the molecular level. Biochemists have discovered that the same chemical compounds and the same central metabolic processes are found in organisms as distantly related as bacteria, plants, and humans.").

${ }^{300}$ Conley \& Makowski, supra note 49, at 309.

${ }^{301} A M P 2,653$ F.3d at 1335. For a more detailed discussion of nucleotides, see Principles at Chapter 19.1.

${ }^{302} A M P 1,702$ F. Supp. 2d at 193-94.

${ }^{303}$ AMP2, 653 F.3d at 1335. See also, Andrew Chin, Artful Prior Art and the Quality of DNA Patents, 57 ALA. L. REV. 975, 981-82 (2006)("The two ends of each strand of a DNA molecule are distinguishable in that the sugar at

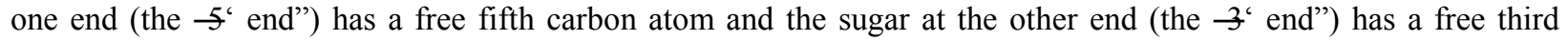
carbon atom. The sequence of each strand is the order of bases in the strand, reading from the $5^{\circ}$ end to the $3^{6}$ end. Two strands can join, or hybridize," to form a DNA molecule (the familiar double helix") if, when the 5' end of a strand is aligned with the $3^{\prime}$ end of another, there is a correspondence of complementary base pairs between their two sequences . . . such sequences are called reverse complements."). For a more detailed discussion of the structure of DNA see HORTON, supra note 299, at 590-97.

${ }^{304}$ Rethinking 1, supra note 300, at 311; HORTON, supra note 299 at 647-48 (in addition to genes that encode proteins, "all cells contain genes that are expressed only in special circumstances, such as during cell division. Multicellular organisms also contain genes that are expressed only in certain types of cells.). The important biological functions of proteins (also called polypeptides) include: acting as enzymes (biochemical catalysts); binding for storage and transport of other molecules; providing support/shape to cells; decoding information in cells; and doing mechanical work such as contraction of muscles.". Id. at 652-53.

${ }^{305}$ See HORTON, supra note 299 , at 16-8.

${ }^{306}$ Harvey Lodish et Al., Molecular Cell Biology 1-3 (6th ed. 2008); see Horton, supra note 299, at 18-9 ("The most obvious of the features that distinguish eukaryotes from prokaryotes is the membrane-bounded nucleus in eukaryotes that contains the chromosomes ... Whereas the genetic material, or genome, of prokaryotes is usually a single circular molecule of DNA, the eukaryotic genome is organized as multiple linear chromosomes.").

${ }^{307}$ AMP1, 702 F. Supp. 2d at 194, 200; Splitting, supra note 33, at 709 ("DNA serves as a template for protein but not the reverse").
} 
Genes are basic units of DNA that are responsible for the inheritance of discrete traits in all living organisms. ${ }^{308}$ Stated slightly differently, the "gene is both the static chemical compound and the dynamic template executed through the genetic code." ${ }^{309}$ Generally each gene contains thousands of nucleotides and -acodes" one or more proteins; in other words each gene contains the information used by the body to produce those proteins. Some of the segments of DNA within a gene - - eons" or - ading sequences" - contain sequences necessary for the creation of a protein. Other segments of DNA - ritrons" - do not code for a protein. ${ }^{310}$ Introns are interspersed between the exons. ${ }^{311}$ "The totality of the genes and the non-coding regions of DNA constituting the genetic material of an organism are referred to as the genome of that organism." 312

\section{$\underline{\text { Production of protein by genes }}{ }^{313}$}

Gene expression is the process by which the information encoded in a gene causes the production of protein. ${ }^{314}$ DNA regions called promoters initiate gene expression. ${ }^{315}$ The synthesis of proteins from genes involves two steps: transcription and translation. ${ }^{316}$

\section{Transcription $^{317}$}

\footnotetext{
${ }^{308}$ AMP1, 702 F. Supp. 2d at 194. See also, Splitting, supra note 33, at 708 ("Genes are identified as the discrete units of DNA sequence that encode individual proteins and that collectively underlie the biochemical design of any organism."); Anita Varma \& David Abraham, DNA is Different: Legal Obviousness and the Balance between Biotech Inventors and the Market, 9 HARV. J. L. TECH. 53, 57 (1996) ("A gene is a region of DNA on a chromosome whose sequence encodes a specific protein."); HORTON, supra note 299, at 647 ("We define a gene as a DNA sequence that is transcribed [see "Transcription" in text below for a summary of transcription]. This definition includes genes that do not encode proteins (not all transcripts are messenger RNA). The definition normally excludes regions of the genome that control transcription but are not themselves transcribed. We will encounter some exceptions to our definition of a gene--surprisingly, there is no definition that is entirely satisfactory.").

${ }^{309}$ Splitting, supra note 33 , at 707 . HorTON, supra note 299 , at 816 , defines the "genetic code" as "The correspondence between a particular three nucleotide codon and the amino acid it specifies. The standard genetic code of 64 codons is used by almost all organisms. The genetic code is used to translate the sequence of nucleotides in mRNA into protein."

${ }^{310} A M P 1,701$ F. Supp. 2d at 194 and $A M P 2,653$ F.3d at 1336.

${ }^{311} A M P 2,653$ F.3d at 1336.

${ }^{312}$ Splitting, supra note 33, at 708. See also Hill, supra 139, at 224 ("The human genome consists of the genetic code of all the genes, gene control sequences, and genetic code with unknown or silent functions. The genome is largely contained in the chromosomes of the cell and is approximately three billion nucleotide pairs. Genes comprise about $2 \%$ of the human genome and number approximately 30,000 to $40,000 . ")$.

${ }^{313}$ See generally HORTON, supra note 299, at chapters 20, 21 and 22, for a detailed description of DNA replication and the production of protein by DNA and RNA.

${ }^{314}$ See LODISH, supra note 306, at G-9; see HORTON, supra note 299, at 822 (a protein is a macromolecule "consisting of one or more polypeptide chains. The biological function of each protein molecule depends not only on the sequence of covalently linked amino acid residues, but also on its three-dimensional structure

(conformation).); id at 811 ("Amino acids are the building blocks of proteins.").

${ }^{315}$ Horton, supra note 299, at 652. See also Hill, supra note 139, at 225 ("although every cell of an organism has the same genome, a cell expresses a different set of genes depending on its function . . . the transcription of a gene can produce variants of its full-length protein that differ in size and function without requiring any alterations in the genomic sequence ... differential gene expression results from exposure to various environmental stimuli . . . Mutations or changes in the gene's DNA sequence occur spontaneously or in response to an environmental mutagen.").

${ }^{316} A M P 1,702$ F. Supp. 2d at 197.

${ }^{317}$ For a more detailed description of transcription, see generally, LODISH, supra note 306, at 120-26 and HORTON, supra note 299 , at $647-80$.
} 
During the first stage (transcription), the sequence of a segment of bases in the DNA is copied, or transcribed, into a related molecule called RNA (ribonucleic acid). ${ }^{318}$ RNA is also made up of nucleotides, but a strand of RNA differs from DNA in that it has a different sugar-phospate backbone than DNA, and the DNA base thymine (T) is replaced by a base called uracil (U). ${ }^{319}$ During transcription, a discrete segment of DNA unwinds ${ }^{320}$ and "each nucleotide on the non-coding, or template, DNA strand is used to make a complementary RNA molecule of the coding DNA strand, i.e., adenine on the template DNA strand results in uracil in the RNA molecule, thymine results in adenine, guanine in cytosine, and cytosine in guanine." ${ }^{321}$ This yields a strand of RNA called pre-RNA, which contains both exons and introns. ${ }^{322}$ The introns are then excised in a process called splicing to produce messenger RNA (or mRNA), which contains only exons. ${ }^{323}$

\section{$\underline{\text { Translation }^{324}}$}

During the second stage in protein synthesis, the mRNA is translated into the encoded protein "via three nucleotide combinations called codons." ${ }^{325}$ A codon encodes "one of the twenty amino acids that make up all proteins or a 'stop' signal that terminates protein translation." ${ }^{326}$ The District Court said, "Because there are only twenty different amino acids but 64 possible codons that can be derived from combinations of the four DNA nucleotides, most amino acids are encoded by more than one DNA codon." 327 Sixty-four codons code for these twenty amino acids, a property that biologists call -dgeneracy., 328

\section{Extracted and purified (i.e., isolated) DNA}

Researchers can extract DNA from its cellular environment, including associated chromosomal proteins, using a number of established laboratory techniques. A particular segment of DNA, such as a gene, may then be excised from the extracted DNA in which it is embedded to obtain "purified" DNA. Researchers may also chemically synthesize DNA molecules in the laboratory. ${ }^{329}$

In $A M P$, the District Court said that -native DNA' . . is packaged, along with proteins, into complex structures known as chromosomes, which contain the vast majority of the genes located in the

${ }^{318} A M P 1,702$ F. Supp. 2d at 197.

${ }^{319} A M P 2,653$ F.3d at 1336.

${ }^{320} A M P 1,702$ F. Supp. 2 d at 197.

${ }^{321} A M P 2,653$ F.3d at 1336.

${ }^{322}$ AMP2, 653 F.3d at 1336. See also AMP1, 701 F. Supp. $2 \mathrm{~d}$ at 197 (the District Court referred to this as premessenger RNA" or -pre-mRNA").

${ }^{323}$ AMP2, 653 F.3d at 1336. See also HoRTON, supra note 299, 677-78.

${ }^{324}$ For a more detailed description of translation, or protein synthesis, see LoDISH, supra note 306, at 127-31 and HORTON, supra note 299, at 638-718.

${ }^{325} A M P 2,653$ F.3d at 1337.

${ }^{326} I d$.

${ }^{327} A M P 1,702$ F. Supp. at 194.

${ }^{328}$ Varma \& Abraham, supra note 308, at 57-8; Splitting, supra note 33, at 709; and Rethinking 1, supra note 300, at 312-13. See also Chin, supra note 303 at 982 ("Some of the sixty-four codons encode the same amino acids, while others do not encode amino acids at all, but signal the end of the polypeptide chain (-stop_codons"). The resulting redundancy in the encoding scheme is known as the -degeneracy" of the genetic code. This degeneracy implies that many different DNA molecules may encode the same amino acid sequence."). See also HoRTON, supra note 299, at 685 ("The degeneracy of the genetic code minimizes the effects of mutations since changing a single nucleotide often results in a codon that still specifies the same amino acid.").

${ }^{329}$ AMP1, 702 F. Supp. 2d at 196. 
cells of the human body." ${ }^{330}$ The court used the term -xtracted DNA" to refer to DNA that had been removed from the cell and separated from other non-DNA materials in the cell (e.g., proteins). The court referred to -prified DNA" to refer to extracted DNA which had been further processed to separate the particular segment of DNA of interest from the other DNA in the genome. The court referred to $\rightarrow$ snthesized DNA" to refer to DNA which had been synthesized in the laboratory. ${ }^{331}$ This article uses those terms in the same manner here.

As noted above, unlike purified or synthesized DNA, native DNA is not typically floating freely in cells of the body, but is "packaged" into chromosomes. However, as part of natural processes "when DNA is copied, or replicated, in preparation for cell division, short segments of DNA are dissociated from the chromosomal proteins, although they are still contained within the cell." ${ }^{332}$ Also as part of natural processes, "when a particular portion of DNA is transcribed into RNA, segments of DNA exist dissociated from the proteins normally bound to it." 333

Researchers may use purified or synthesized DNA as tools for biotechnological applications for which native DNA cannot be used. For example, unlike native DNA, researchers may use purified or synthesized DNA as a - prbe" to target and bind to a particular segment of DNA, thus allowing the detection of targeted DNA sequences through the use of standard laboratory machinery. Scientists can also use purified or synthesized DNA as a - pimer" (a) to sequence a targeted DNA to determine the order of nucleotides in a DNA molecule, or (b) to perform polymerase chain reaction (-PR") amplification, a process which utilizes targeted DNA specific primers to duplicate the quantity of target DNA exponentially. ${ }^{334}$

\section{cDNA}

Complementary DNA, or -DNA," is a type of DNA molecule catalyzed by a protein known as -averse transcriptase" generated from mRNA during -averse transcription." 335 cDNA is -omplementary" to the mRNA from which it is produced in that each base in the cDNA can bind to the corresponding base in the mRNA from which it is generated. A cDNA molecule represents an exact copy of one of the protein coding sequences encoded by the native DNA, even though differences exist in its physical form. ${ }^{336}$

"During reverse transcription, each base of the mRNA serves as a clamp for its complementary nucleotide to be incorporated into the new cDNA molecule while the chemical bonds between the nucleotides of the cDNA strand are formed. Much like transcription, uracil on the mRNA binds to and

\footnotetext{
${ }^{330} I d$. at 195.

${ }^{331} I d$. at 196. lipid membranes and protein cytoskeletons).

${ }^{333} A M P 1,702$ F. Supp. 2d at 196. tangible form).").

${ }^{335}$ AMP1, 702 F. Supp. 2d at 198; HoRTON, supra note 299, at 729, 823.

${ }^{336} A M P 1,702$ F. Supp. 2d at 198.
}

${ }^{332}$ Id. See also HorTON, supra note 299, at 11, 18-22, 253-92 (cells also contain numerous other structures, such as

${ }^{334}$ Id. at 196-97. See also, Arti K. Rai, Intellectual Property Rights in Biotechnology: Addressing New Technology, 34 WAKE FOREST L. REV. 827, 832 (1999) ("Once the gene for a protein is isolated, the gene can be cloned by inserting it into a bacterial cell. Cloning the gene for a given protein means that large quantities of the protein will then be produced. Producing large quantities of certain proteins, such as insulin or interferon, will often be immensely valuable as a therapeutic matter."). On the other hand, DNA sequencing may not have immediate prospects of commercial application. See Sequences, supra note 190, at 788 (First, high-throughput DNA sequencing typically yields information about DNA sequences for which the corresponding biological functions are not yet understood. .... Second, high-throughput DNA sequencing typically yields considerable chaff (in the form of non-coding sequences and sequences that do not correspond to any apparent commercial products) along with the occasional bit of wheat (in the form of sequences encoding commercially valuable proteins or offering other uses in 
thereby acts as a clamp for the nucleotide adenine, adenine for thymine, guanine for cytosine, and cytosine for guanine." ${ }^{337}$

A scientist typically generates cDNA in a laboratory. ${ }^{338}$ However, cDNA does exist in nature as a result of retroviruses, which are viruses that have two identical RNA strands. ${ }^{339}$ In the life cycle of a retrovirus, "a viral enzyme called reverse transcriptase initially copies the viral RNA genome into singlestranded DNA complementary to the virion RNA; the same enzyme then catalyzes synthesis of a complementary DNA strand." 340

cDNA contains certain structural and functional differences from native DNA. For instance, cDNA does not contain introns. As a result, the production of proteins from cDNA does not require RNA splicing. Some cDNAs cannot be used to produce proteins without the addition of certain regulatory sequences. In addition, native DNA is often (although not always) chemically modified in the body, while cDNA generated in the laboratory is not so modified. cDNA also differs from mRNA in that it is a more stable compound and requires both transcription and translation to produce protein, rather than "simply translation" with mRNA. ${ }^{341}$ A scientist seeking to learn more about a certain protein may transfer a cDNA encoding the protein into a recipient cell that does not normally express that protein. ${ }^{342}$ Then, if "the cDNA is operatively linked to particular 'promoter' sequences that initiate transcription from the cDNA, the recipient cell will then express the protein of interest." ${ }^{143}$

\section{Primers and probes}

Probes are isolated DNA fragments with usually 15-30 nucleotides, and primers are isolated DNA fragments with usually 100-1,000 nucleotides. ${ }^{344}$ Molecular biologists use probes to bind to a particular segment of DNA, allowing detection of the target DNA sequence with standard laboratory machinery. ${ }^{345}$ Molecular biologists use primers to determine the order of nucleotides in a DNA molecule, or to perform polymerase chain reaction (PCR") to duplicate the quantity of target DNA exponentially. ${ }^{346}$

Scientists currently cannot use native DNA as probes or primers, ${ }^{347}$ but not all isolated DNA segments can be used for these purposes either. For instance, "a small fragment of isolated DNA can be used as a primer in order to selectively detect the presence of the BRCA1 gene or BRCA1 gene mutation in a patient." ${ }^{348}$ On the other hand, "the full length gene is too large to be used as a probe" and "an entire isolated gene appears unsuitable for use as a primer in genetic screening for mutations in that same gene." ${ }^{349}$

\footnotetext{
${ }^{337} I d$.

${ }^{338} \mathrm{Id}$.

${ }^{339}$ LODISH, supra note 306 , at 158 .

${ }^{342}$ AMP1, 702 F. Supp. $2 \mathrm{~d}$ at 199. transcription initiation").

${ }^{344} A M P 1,702$ F. Supp. 2d at 196-97 and infra notes 13-14.

${ }^{345} A M P 1,702$ F. Supp. $2 d$ at 196.

${ }^{346} I d$. at 197.

${ }^{347} I d$. at 196.

${ }^{348}$ AMP2, 653 F.3d at 1363 .

${ }^{349} I d$. at 31 .
}

${ }^{340} I d$. (A "virion" is "an individual viral particle"). For additional discussion of retroviruses, see id. at 159, 229-30.

${ }^{341}$ AMP1, 702 F. Supp. 2d at 198-99 (finding a "naturally occurring cDNAs, known as 'pseudogenes,' exist in the human genome and are structurally, functionally, and chemically identical toCDNAs made in the laboratory," neither the Majority nor the Concurrence discuss this finding, but the dissent did in AMP2, 653 F.3d at 1378, n.5).

${ }^{343}$ Id.; HORTON, supra note 299, at 822 (a promoter is the region of DNA where RNA polymerase binds during 